\title{
Square Peg in a Round Hole: Government Contractor Battlefield Tort Liability and the Political Question Doctrine
}

\author{
Chris Jenks* \\ I. \\ INTRODUCTION
}

As the United States military's involvement in Iraq and Afghanistan enters its seventh and ninth year respectively, there are as many or possibly more contract employees than uniformed service members in the two combat theatres. ${ }^{1}$ This reliance on contractors is nothing new; George Washington's

* Lieutenant Colonel, U.S. Army Judge Advocate General's (JAG) Corps. LL.M. with distinction, Georgetown University Law School (2009); LL.M., The Judge Advocate General's Legal Center and School (2006); J.D., University of Arizona (2001); B.S., United States Military Academy (1992). Currently assigned as the Chief of the International Law Branch, the Office of Tthe Judge Advocate General, Rosslyn, VA. Relevant previous assignments include Deputy Chief, Senior Litigation Attorney, and Tort Litigation Attorney, U.S. Army Litigation Division, Arlington, VA (2006-2008) and General Counsel and Chief Prosecuting Attorney, Operation Iraqi Freedom, Mosul, Iraq (2004-2005); Member of the Bars of Arizona and the United States Supreme Court. The views expressed in this Article are those of the author and not the JAG Corps, the United States Army, or the Department of Defense. Special thanks to Colonel (retired) Rich Hatch, former Chief of the Army's Litigation Division, and Professor Jim Schoettler, Georgetown University Law School, for their assistance.

1. Reinforcing the adage that "there are lies, damn lies, and statistics," statistics on both contract and military personnel involved in the conflicts in Iraq and Afghanistan widely vary. See MARK TWAIN, CHAPTERS FROM MY AUTOBIOGRAPHY 186 (1907), available at http:/www.gutenberg.org/ebooks/19987. While Twain attributes the phrase to Disraeli, the exact origins are unclear. The Congressional Budget Office reported in August 2008 that "as of early 2008 , at least 190,000 contractor personnel, including subcontractors, were working on U.S. funded contracts in the Iraq theatre." CONG. BUDGET OFFICE, CONTRACTORS' SUPPORT OF U.S. OPERATIONS IN IRAQ, 1 (2008) [hereinafter CBO]. In October 2008, the Government Accounting Office reported that as of January 2008, the Department of Defense alone employed 200,111 contract personnel in Iraq and Afghanistan. Gov'T ACCOUNTABILITY OFFICE, GAO-09-19, CONTINGENCY CONTRACTING DOD, STATE AND USAID CONTRACTS AND CONTRACTOR PERSONNEL IN IRAQ AND AFGHANISTAN, 25 (2008) [hereinafter GAO]. For discussion of the variations in reported military personnel numbers and the different methods used to calculate troop strength see CONG. RESEARCH SERVICE, RL33110, THE COST OF IRAQ, AFGHANISTAN AND OTHER 178 
Continental Army utilized contractors. ${ }^{2}$ Yet, while not new, the current utilization of contractors is both quantitatively ${ }^{3}$ and qualitatively ${ }^{4}$ different than in previous military operations. In odd contrast to the seeming embrace of contractors, according to a November 2009 report, the U.S. Government does not know how many contractors it employs in Iraq and Afghanistan. ${ }^{5}$ Possibly even more striking, the U.S. Government is not tracking the number of contract employees wounded or killed in Iraq and Afghanistan. ${ }^{6}$

This incongruous combination of necessity and apathy arguably defines, at least in part, the relationship between the United States government and the contractors it employs. It also serves as backdrop for a host of civil lawsuits filed against those contractors stemming from work done at the behest of the U.S. government. ${ }^{7}$ These lawsuits stem from alleged wrongs committed in both Iraq and Afghanistan, and have been filed by plaintiffs ranging from former detainees $^{8}$ suing contract interrogators and interpreters, to contract employees ${ }^{9}$

GLOBAL WAR ON TERROR OPERATIONS SINCE 9/11, 36-37 (2008) [hereinafter CRS].

2. See Stephen M. Blizzard \& Marsha Kwolek, Increasing Reliance of Contractors on the Battlefield: How Do We Keep From Crossing the Line?, A.F. J. LoGISTICS 142,144-145 (2004) (noting that "General George Washington's Continental Army relied on civilians for transportation, carpentry, engineering, food, and medical services").

3. In terms of the quantitative difference, the Congressional Budget Office reports that the current ratio of contractor to military personnel in Iraq is "at least 2.5 times higher than the ratio during any other major U.S. conflict..." CBO, supra note 1, at 1 . The budget office report provides an informative table which lists an estimated ratio of contractor to military personnel. Id. at 13 (citing William W. Epley, Civilian Support of Field Armies, 22 ARMY LOGISTICIAN 30 (1990). See also Steven Zamparelli, Contractors on the Battlefield: What Have We Signed Up For?, 23 A.F. J. LOGISTICS 11 (1999) [hereinafter Zamparelli]; DEP'T OF DEFENSE, DEPARTMENT OF DEFENSE REPORT ON DOD PROGRAM FOR PLANNING, MANAGING, AND ACCOUNTING FOR CONTRACTOR SERVICES AND CONTRACTOR PERSONNEL DURING CONTINGENCY OPERATIONS 12 (2007).

4. In terms of the qualitative difference, see JOINT CHIEFS OF STAFF, JOINT PuB. 4-0, DOCTRINE FOR LOGISTICAL SUPPORT OF JOINT OPERATIONS V-I (2008) [hereinafter JOINT PUB. 4-0] (describing DoD's increasing reliance on contractors to perform a wide range of functions and tasks); U.S. DEP'T OF ARMY, FIELD MANUAL 3-100.21, CONTRACTORS ON THE BATTLEFIELD 1-2 (2003) ("When considering contractor support, it should be understood that it is more than just logistics; it spans the spectrum of combat support (CS) and combat service support (CSS) functions.").

5. Gov'T ACCOUNTABILITY OFFICE, GAO-10-187 CONTINGENCY CONTRACTING FuRTHER IMPROVEMENTS NEEDED IN AGENCY TRACKING OF CONTRACTOR PERSONNEL AND CONTRACTS IN IRAQ AND AFGHANISTAN, (2009) [hereinafter GAO contractor tracking] (describing the reporting by USAID, DoS and DoD of contractors in Iraq and Afghanistan as incomplete and unreliable).

6. GAO, supra note 1, at 27-28, 33, and 38. See Steven Schooner, Remember Them, Too: Don't Contractors Count When We Calculate The Costs of War?, WASH. POST, May 25, 2009, at A21.

7. See generally, Cedric Ryngaert, Litigating Abuses Committed by Private Military Companies, 19 EUR. J. INT'L L. 1035 (2008).

8. Suits involving former detainees claiming to have been tortured by contract employees while detained in Iraq include: Ibrahim v. Titan \& CACI (Ibrahim I), 391 F. Supp. 2d 10 (D.D.C. 2005); Saleh v. Titan \& CACI, 436 F. Supp 2d 55 (D.D.C. 2006) ; Al-Quraishi v. Nakhla, 8:08-cv01696-PJM (D. Md. June 30, 2008) (PACER); and Al-Shimari v. CACI, 1:08-cv-00827-GBL-JFA 
suing contractors following insurgent attacks, to U.S. service members ${ }^{10}$ suing contractors after vehicle and airplane crashes. The majority of the lawsuits involve tort claims which on their face do not seem to implicate complicated constitutional issues. ${ }^{11}$ But, in at least seventeen cases brought against military contractors thus far, the defendants have raised just such issues by asserting the political question doctrine as a defense. ${ }^{12}$

(E.D. Va. June 30, 2008) (PACER).

9. Contractor employee suits include: Smith v. Halliburton, No. 06-0462, 2006 WL 2521326 (S.D. Tex. Aug. 30, 2006) (estate of a contract employee filed suit after a suicide bomber detonated a suicide vest in a Kellogg, Brown \& Root (KBR) operated dining facility on a U.S. military base in Iraq); Woodson v. Halliburton, No. H-06-2107, 2006 WL 2796228 (S.D. Tex. Sept. 28, 2006) (suit filed by former KBR employee stemming from an insurgent act on a supply convoy in which plaintiff was a driver); Fischer v. Halliburton, 454 F. Supp. 2d 637 (S.D. Tex. 2005); Lane v. Halliburton, No. 06-1971, 2006 WL 2796249 (S.D. Tex. Sept. 26, 2006); and Smith-Idol v. Halliburton, No. 06-1168, 2006 WL 2927685 (S.D. Tex. Oct. 11, 2006) (plaintiffs or their family members were among 18 drivers killed, missing, or injured following an April 2004 attack on a fuel convoy in Iraq).

10. Service member suits include: McMahon v. Presidential Airways, 502 F.3d 1331 (9th Cir. 2007) (suit by the estates of three U.S. service members killed when the contractor-operated plane in which they were passengers crashed during a November 2004 flight in Afghanistan); Harris v. KBR, 2:08-cv-00563 (W.D. Penn. Apr. 22, 2008) (PACER) (wrongful death suit by the survivors of a U.S. Army Staff Sergeant electrocuted in January 2008 while showering at a facility in Iraq for which KBR was allegedly responsible for maintaining); Baragona v. Kuwait Gulf Link Transport Co., No.1:05-cv-1267-WSD, 2007 WL 4125734 (N.D. Ga. Nov. 5, 2007) (wrongful death suit filed by the survivors of a U.S. Army officer killed when his military vehicle was struck by a Kuwaiti Gulf Link Transport Company vehicle in May 2005); Bucklin v. Halliburton, 4:07-cv-01522 (S.D. Tex. May 7, 2007) (PACER) (wrongful death suit by the estate of Army Corporal killed in May 2005 by a cable being used to pull a stuck KBR vehicle); Monroe v. Erinys, 4:07-cv-03528 (S.D. Tex. Oct. 10, 2007) (PACER) (wrongful death suit by the father of a U.S. Army NCO killed when his vehicle was struck by one driven by a British private security company); Carmichael v. KBR (Carmichael I), 450 F. Supp. 2d 1373 (N.D. Ala. 2006) (guardian of U.S. Army Sergeant filed suit for injuries he suffered while performing security duty for a KBR fuel tanker which overturned); Lessin v. KBR, CIVA-H-05-01853, 2006 WL 3940556 (S.D. Tex. June 12, 2006) (suit by U.S. Army soldier injured by a KBR vehicle); Potts v. DynCorp Int'l, 465 F. Supp. 2d 1245 (M.D. Ala. 2006) (suit by U.S. Army Soldier injured when a vehicle driven a contractor flipped over); Whitaker v. KBR, $444 \mathrm{~F}$. Supp. 2d 1277 (M.D. Ga. 2006) (suit by family of Army Soldier who fell into and drowned in the Tigris river in Iraq in April 2004 following a traffic accident involving KBR); and Webster v. Halliburton, 4:05-cv-03030 (S.D. Tex. Aug. 26, 2005) (PACER) (wrongful death suit by the estate of Army non-commissioned officer killed when his military vehicles was struck by a KBR vehicle in Iraq). See also Ben Davidson, Liability on the Battlefield: Adjudicating Tort Suits Brought by Soldiers Against Military Contractors, 37 PuB. CoNT. L.J. 803 (2008).

11. Which is not to suggest that a constitutional issue is per se required for the application of the political question doctrine. Indeed, as Professor Henkin states, "presumably, courts may, or must abstain on a 'political question' in any kind of case, not only where constitutional issues are raised." LOUIS HENKIN, FOREIGN AFFAIRS AND THE CONSTITUTION 145 (2nd ed. 1996).

12. The seventeen cases are: Al-Quraishi, 8:08-cv-01696-PJM (PACER); Al-Shimari, 1:08-cv00827-GBL-JFA (PACER); Saleh, 436 F. Supp 2d 55; Ibrahim 1, 391 F. Supp. 2d 10; Smith, 2006 WL 2521326; Fischer, 454 F. Supp. 2d 637; Lane, 2006 WL 2396249; Smith-Idol, 2006 WL 2927685; Woodson, 2006 WL 2796228; McMahon, 502 F.3d 1331; Harris, 2:08-cv-00563 (PACER); Bucklin, 4:07-cv-01522 (PACER); Carmichael I, 450 F. Supp. 2d 1373; Lessin, 2006 WL 3940556; Potts, 465 F. Supp. 2d 1245; Whitaker, 444 F. Supp. 2d 1277; and Webster, 4:05-cv-03030 
The doctrine, which traces back to Marbury v. Madison, ${ }^{13}$ "excludes from judicial review those controversies which revolve around policy choices and value determinations constitutionally committed for resolution to the halls of Congress or the confines of the executive branch."14 Despite the political question doctrine's longevity, over time, the doctrine has been subject to various interpretations and been inconsistently applied, yielding more confusion than clarity. ${ }^{15}$ There have even been periods in which commentators questioned whether the doctrine still existed. ${ }^{16}$

While the present use of the doctrine proves its existence, its confused application in the contractor cases analyzed in this Article raises questions concerning the appropriateness of applying the doctrine in battlefield-related contractor tort litigation. The fundamental aim of the political question doctrine is to address whether the judiciary should review government action or decisions. And yet, private contractors are the ones asserting the defense in cases where the government is not a named party and has yet to intervene or submit an amicus brief. ${ }^{17}$ Seen in this light, the confused application of the doctrine to the contractor cases analyzed in this Article, and the correspondingly inconsistent decisions which follow are to be expected. But, more importantly, the application of the political question doctrine in these cases raises fundamental questions about the appropriateness of applying the doctrine in battlefield-related contractor tort litigation altogether-questions this Article seeks to address.

This Article examines the use of the political question doctrine as a defense

(PACER).

13. Marbury v. Madison, 5 U.S. (1 Cranch) 137 (1803).

14. Japan Whaling Ass'n v. American Cetacean Soc'y, 478 U.S. 221, 230 (1986).

15. Justice Brennan, author of the seminal Baker v. Carr opinion, acknowledged that the political question doctrine was comprised of "attributes which, in various settings, diverge, combine, appear, and disappear in seeming disorderliness." Baker v. Carr, 369 U.S. 186, 210 (1962).

16. See, e.g., Louis Henkin, Is There a Political Question Doctrine?, 85 YALE L.J. 597 (1976); Linda Sandstrom Simard, Standing Alone: Do We Still Need a Political Question Doctrine?, 100 DICK. L. REV. 303 (1996). But see ERWIN CHEMERINSKY, FEDERAL JURISDICTION 142, 143-44 (2nd ed. 1994) (questioning the existence of the political question doctrine but ultimately acknowledging its existence while labeling it "the most confusing of the justiciability doctrines" and critiquing the doctrine's name and the varying definitions assigned it by the Supreme Court, as well as "the Court's failure to articulate useful criteria for deciding what subject matter presents a nonjusticiable political question"); CHARLES WRIGHT, THE LAW OF FEDERAL COURTS 74-75 (4th ed. 1983) (claiming that "[n]o branch of the law of justiciability is in such disarray as the doctrine of the "political question," that "there is no workable definition of characteristics that distinguish political questions from justiciable questions," and the doctrine is "more amenable to description by infinite itemization than by generalization").

17. See Joanna E. Herman \& Jae Hong Lee, The Political Question Doctrine: A Potential Weapon For Military Contractors, SkYwRITINGS Spring 2008 at 18 (emphasis added); David Kasanow \& Lisa M. Norrett, Defending Battlefield Contractors in Tort Suits: A Survey of Available Legal Theories (Jan. 24 2008) (unpublished practitioner's note, on file with author). 
in tort litigation against government contractors stemming from the conflicts in Iraq and Afghanistan. In the next section, the origins and evolution of the political question doctrine are reviewed as well as the difficulties that result when the doctrine is applied to the military. Section three explores, through a series of case comparisons, how those difficulties manifest themselves in the varied analyses and outcomes in recent contractor litigation. The fourth section considers the government's role in creating some of the confusion involved in wartime contractor tort liability jurisprudence where it has considered the political question doctrine and explores the ramifications of the government's conspicuous silence concerning the same. In the final section, confusion from the inconsistent application of the political question doctrine is assessed and a methodology is proposed in the hopes of bringing greater clarity and consistency to future rulings. Ultimately, the Article concludes that, absent changes in the government's attitude toward the litigation and a more rigorous analytical approach by the judiciary, the confusion surrounding the political question doctrine and the inconsistency of its application will only increase.

II.

The Political Question Doctrine

\section{A. Origin and Evolution}

The political question doctrine dates back to 1803 and Chief Justice John Marshall's defining opinion in Marbury v. Madison, which established the doctrine of constitutional judicial review in the United States. ${ }^{18}$ Chief Justice Marshall explained that it is "emphatically the province and duty of the judicial department to say what the law is." 19 In Marbury, Justice Marshall outlined the delicate balance "that for every violation of a vested right, there should be a legal remedy" but that "not all disputes are susceptible to judicial resolution."20 Stated more plainly, Marshall explained that "[q]uestions, in their nature political, or which are by the constitution and laws, submitted to the executive, can never be made in this court." 21 Under this construct, some government actions are political acts that are not examinable in a court of justice. ${ }^{22}$ To what extent and under what circumstances the conduct of military contractors equates to or implicates the government action Marshall spoke of is a central issue in the present day litigation.

In the early twentieth century, the Supreme Court reframed Marshall's

18. See Marbury, 5 U.S. (1 Cranch) at 137.

19. Id. at 177 .

20. Curtis A. Bradley \& Jack L. Goldsmith, Foreign Relations LAW 47 (2006).

21. Marbury, 5 U.S. (1 Cranch) at 165-166.

22. Id. at $164-165$ (emphasis added). 
formulation in Oetjen v. Cent. Leather Co., stating that "[t]he conduct of the foreign relations of our government is committed by the Constitution to the Executive and Legislative--'the political'-Departments of the Government, and the propriety of what may be done in the exercise of this political power is not subject to judicial inquiry or decision." ${ }^{23}$ Yet, in so doing, the Court failed to define the parameters of government "conduct." By 1950, the Court considered the limitations on judicial review of the executive branch deploying the military, as raised in Johnson v. Eisentrager. ${ }^{24}$ Here, the Court provided some insight on at least this realm of government conduct. The Court held that "[c]ertainly it is not the function of the Judiciary to entertain private litigation even by a citizen-which challenges the legality, the wisdom, the propriety of the Commander-in-Chief in sending our armed forces abroad or to any particular region."

The Court signaled its willingness to reexamine what sorts of government action were appropriate subjects of judicial review in 1961 in a case that legal scholars consider the cornerstone of modern interpretation and application of the political question doctrine, ${ }^{25}$ Baker v. Carr. ${ }^{26}$ In Baker, the Court reaffirmed Marshall's 1806 characterization of itself as "the ultimate interpreter of the Constitution" and again assigned itself responsibility for the "delicate exercise of constitutional interpretation." 27 The Court explained that this amounted to "[d]eciding whether a matter has in any measure been committed by the Constitution to another branch of government, or whether the action of that branch exceeds whatever authority has been committed." 28

To the already complex task of determining where, and to what degree, the Constitution has committed a matter to another branch of government, the Court outlined an additional challenge that the political doctrine question analysis

23. Oetjen v. Cent. Leather Co., 246 U.S. 297, 302 (1918).

24. Eisentrager addressed whether German nationals captured and tried by military commission in China by the U.S. Army after the end of World War II were entitled to file a writ of habeas corpus petition in a U.S. court. While the case focused on the applicability of the writ, one of the German national petitioners' arguments was that the presence of the U.S. military in China was unconstitutional. 339 U.S. 763, 789 (1950).

25. See J. Peter Mulhern, In Defense of the Political Question Doctrine, 137 U. PA. L. REv. 97, 105-06 (1988) (discussing the dominance of Baker v. Carr in judicial analysis of the political question doctrine in federal courts); Mark Tushnet, Law and Prudence in the Law of Justiciability: The Transformation and Disappearance of the Political Question Doctrine. 80 N.C. L. REv. 1203, 1206-13 (2001) (analyzing the "doctrinalization" of the political question doctrine through the lens of the doctrine's lead case, Baker v. Carr); WEST's ENCYCLOPEDIA OF AMERICAN LAW 450 (2nd ed. 2005) (referring to Baker v. Carr as a "landmark" case due to its influence over redistricting issues, but also because it created the analytical framework that continues to govern political question disputes).

26. Baker dealt with an equal protection claim stemming from a state legislative apportionment system for state representatives. 369 U.S. 186 (1962).

27. Id. at 211 .

28. Id. 
poses. The Court stated that "not only does resolution of [foreign relations] issues frequently turn on standards that defy judicial application, or involve the exercise of a discretion demonstrably committed to the executive or legislature; but many such questions uniquely demand a single-voiced statement of the Government's views." 29 While the Court insisted that the judiciary retained a role, on a pragmatic level the Court failed to define the parameters of that role. In turning away from the idea, espoused by Oetjen ${ }^{30}$ and Eisentrager, ${ }^{31}$ that judicial review of foreign policy matters was inappropriate, the Court in Baker announced that "it is error to suppose that every case or controversy which touches foreign relations lies beyond judicial cognizance." 32

In Baker, the Supreme Court acknowledged that "[m]uch confusion results from the capacity of the political question label to obscure the need for case-bycase inquiry" 33 while stressing that determining whether or not the issues raised by a case fell beyond judicial cognizance nevertheless required a discriminating case-specific analysis. ${ }^{34}$ In Baker, the Court attempted to define the parameters for cases and controversies the judiciary would, and would not, examine. ${ }^{35}$ The Court listed "several formulations," which "vary slightly according to the setting in which the questions that arise may describe a political question, although each has one or more elements which identify it as essentially a function of the separation of powers." 36 The Baker formulations are:

[1] [A] textually demonstrable constitutional commitment of the issues to a coordinate political department; or [2] a lack of judicially discoverable and manageable standards for resolving it; or [3] the impossibility of deciding without an initial policy determination of a kind clearly for non judicial discretion; or [4] the impossibility of a court's undertaking independent resolution without expressing lack of the respect due coordinate branches of government; or [5] an unusual need for unquestionable adherence to a political decision already made; or [6] the potentiality of embarrassment from multifarious pronouncements by various departments on one question. ${ }^{37}$

\footnotetext{
29. Id.

30. See Oetjen, 246 U.S. at 297.

31. See Johnson v. Eisentrager, 339 U.S. 763 (1950).

32. Baker, 369 U.S. at 211.

33. Id.

34. Id.

35. Id.

36. Id. at 217.

37. Id. More recently, the Court described the six Baker "formulations" as "six independent tests." Vieth v. Jubelirer, 541 U.S. 267, 277 (2004). Accordingly, hereinafter they are referred to as tests. Additionally, while the Baker Court merely listed the tests, the Vieth Court, while maintaining the same order as in Baker, numbered the tests and explained that "[ $t]$ hese tests are probably listed in descending order of both importance and certainty." Id. at 278 . This approach was arguably the logical result of how the Court had previously considered and weighted the tests. For example, in Powell v. McCormack, the Court conducted an extensive analysis of the first test and then consolidated the analysis of the remaining five tests in two paragraphs. 395 U.S. 486, 548-549
} 
The Baker framework envisioned "a discriminating analysis of the particular question posed, in terms of the history of its management by the political branches, of its susceptibility to judicial handling in the light of its nature and posture in the specific case, and of the possible consequences of judicial action." 38 Whether or not one of these tests is "inextricable" from the case determines whether dismissal on the basis of the political question doctrine is appropriate. The plain meaning of inextricable refers to whether the elements of a claim can or cannot be disentangled from issues committed to or decision making by one of the branches of government. As discussed later, each side has inherent incentives to either avoid or implicate such issues or decision making. It follows that this should reinforce the importance of the government weighing in on whether a political question is involved, but the case history demonstrates that this has not come to pass.

The Court discarded the possibility of resolving political question cases through "semantic cataloguing," 39 yet it reached its decision in Baker by "analyz[ing] representative cases and infer[ring] from them the analytical threads that make up the political question doctrine." 40 However, notwithstanding the Court's efforts to articulate a distinction, the difference between the prohibited semantic cataloging and a permissible inference from analytical threads is illusory. Indeed a judicial inquiry to identify representative cases is cataloging, "semantic" or otherwise. For the Supreme Court to caution lower courts from relying on cataloging while encouraging its functional equivalent, styled as "analytical threads," creates a false, confusing, and unhelpful distinction. Given this inherent contradiction in Baker, it should not come as a surprise that, in subsequent cases, the Court found analytical threads that do lend themselves to cataloguing, further confusing the judiciary in the process. $^{41}$

Although most cases involving foreign affairs defy clean application of the Baker tests, Baker remains the starting point for assessing the application of the political question doctrine to the executive branch's employment of the military. ${ }^{42}$ A review of the political question doctrine as applied in Gilligan $v$.

(1969). Notwithstanding the number and labeling of the tests as independent, discrete analysis of an individual test seems unlikely. See Nixon v. United States, 506 U.S. 224, 228-29 (1993) (explaining the connection between what is now referred to as the first and second Baker tests).

38. Baker, 369 U.S. at 211-212.

39. Id.

40. Id. at 211 .

41. See, e.g., Japan Whaling Ass'n v. American Cetacean Soc'y, 478 U.S. 221, 230 (1986) (determining that interpretation of statutes involving foreign affairs is a justiciability question); Goldwater v. Carter, 444 U.S. 996 (1979) (concluding that a challenge to the President's unilateral termination of a treaty presents a political question).

42. See Gilligan v. Morgan, 413 U.S. 1, 11 (1973) (stating that just because [the political question] doctrine has been held inapplicable to certain carefully delineated situations, it is no reason 
Morgan, a case involving military functions, sets the stage for understanding the increased difficulty and resulting confusion when the doctrine is applied to cases involving military functions contracted out by the government in Iraq and Afghanistan.

\section{B. Gilligan v. Morgan: Political Question Doctrine Applied to Military Functions}

There is little in the way of a discernible pattern to how courts at all levels interpret and apply the Baker tests. The Supreme Court case Gilligan v. Morgan illustrates the difficulties that political question cases dealing with the military present. Gilligan stemmed from an incident at Kent State University where members of the Ohio National Guard wounded and killed several students in $1970 .{ }^{43}$ The Court in Gilligan reviewed a challenge to military readiness decisions made by the Ohio National Guard. ${ }^{44}$

Initially, the district court dismissed the case for failing to state a claim upon which relief could be granted, but the U.S. Court of Appeals for the Sixth Circuit reversed and remanded the case to the district court to answer the question of whether there was a pattern of training, weaponry and/or orders within the Ohio National Guard which made the use of lethal force at Kent State inevitable. ${ }^{45}$ The Supreme Court, in turn, addressed the appropriateness of judicial involvement with the issues underlying both this question and the request for injunctive relief which sought to limit the Governor's use of the National Guard. ${ }^{46}$ The Supreme Court cited with approval to Judge Calebrezzi's dissent from the Sixth Circuit's ruling. ${ }^{47}$ In his dissent, Judge Calebrezzi explained how the Baker tests precluded judicial regulation of National Guard training and equipment:

I believe that the congressional and executive authority to prescribe and regulate the training and weaponry of the National Guard, as set forth above, clearly precludes any form of judicial regulation of the same matters. I can envision no form of judicial relief which, if directed at the training and weaponry of the National Guard, would not involve a serious conflict with a "'coordinate political department; . . . a lack of judicially discoverable and manageable standards for resolving [the question]; . . the impossibility of deciding without an initial policy determination of a kind clearly for nonjudicial discretion; . . . the impossibility of a court's undertaking independent resolution without expressing lack of the

for federal courts to assume its demise"); Davis v. Bandemer, 478 U.S. 109, 123-27 (1986) (reviewing the Baker formulations and reaffirming the Court's commitment to Baker while "declining Justice O'Connor's implicit invitation to rethink [the Baker] approach").

43. See Gilligan, 413 U.S. at 11.

44. Id. at 10 .

45. Id.

46. See id.

47. Id. at 8 . 
respect due coordinate branches of government; . . . an unusual need for unquestioning adherence to a political decision already made; [and] the potentiality of embarrassment from multifarious pronouncements by various departments on one question.' . . ." Any such relief, whether it prescribed standards of training and weaponry or simply ordered compliance with the standards set by Congress and/or the Executive, would necessarily draw the courts into a nonjusticiable political question, over which we have no jurisdiction. ${ }^{48}$

Based on this reasoning, one possible interpretation of Gilligan is that it provides guidance on the parameters and limitations of judicial review of the military. ${ }^{49}$ Yet another interpretation of Gilligan, suggested by the Court in a later case, makes determinant whether the plaintiffs were requesting injunctive relief from ongoing or future conduct or damages for injury arising from past conduct. Where the plaintiffs sought injunctive relief, including in Gilligan, the Court heard the case and applied the political question doctrine, reversing the Sixth Circuit for not dismissing Gilligan. ${ }^{50}$ In contrast, a year later, the Supreme Court again reversed the Sixth Circuit, this time in Scheuer, for dismissing a damages suit against the governor of Ohio and the head of the Ohio National Guard arising out of the Kent State shootings. ${ }^{51}$ In Gilligan, the court noted that

[T]his is not a case in which damages are sought for injuries sustained during the tragic occurrence at Kent State. Nor is it an action seeking a restraining order against some specified and imminently threatened unlawful action. Rather, it is a broad call on judicial power to assume continuing regulatory jurisdiction over the activities of the Ohio National Guard. This far-reaching demand for relief presents important questions of justiciability..$^{52}$

One means of reconciling these decisions is to assert that the Court was

48. Id. (emphasis in original).

49. In the Court's words,

"[i]t would be difficult to think of a clearer example of the type of governmental action that was intended by the Constitution to be left to the political branches directly responsible - as the Judicial Branch is not-to the electoral process. Moreover, it is difficult to conceive of an area of governmental activity in which the courts have less competence. The complex, subtle, and professional decisions as to the composition, training, equipping, and control of a military force are essentially professional military judgments, subject always to civilian control of the Legislative and Executive Branches. The ultimate responsibility for these decisions is appropriately vested in branches of the government which are periodically subject to electoral accountability. It is this power of oversight and control of military force by elected representatives and officials which underlies our entire constitutional system; the majority opinion of the Court of Appeals failed to give appropriate weight to this separation of powers."

Id. at 10-11 (emphasis in original).

50. Id. at 5 .

51. Scheuer v. Rhodes, 416 U.S. 232 (1974), abrogated by Harlow v. Fitzgerald, 457 U.S. 800 (1982), but on other grounds.

52. Gilligan, 413 U.S. at 5. 
more inclined to invoke the political question doctrine in Gilligan because injunctive relief against the military would require greater judicial intrusion into essential military functions. Yet, even where the requested relief is limited to monetary damages, as in Scheuer, the district court would seem to be on almost equally unsteady footing in hearing a case to recover damages for injuries suffered stemming from scenarios implicating the military. In either case, the judiciary would deprive the executive and legislative branches of the "ultimate authority" in areas textually committed to those branches by the Constitution.

A court focusing on the distinction between injunctive and monetary relief established in Gilligan and Scheuer would seem to be following the edict in Baker "to analyze representative cases and to infer from them the analytical threads" as a way to determine the applicability of the political question doctrine..$^{53}$ However, this arguably false, or at least superficial, dichotomy between forms of relief only serves to mask the difficulties courts face in trying to identify real analytical threads from cases involving military functions.

These difficulties are readily apparent in recent litigation involving U.S. government contractors working in Iraq and Afghanistan. Understandably, courts seem to struggle with the applicability of the political question doctrine to the expanding role of contractors in battlefield or quasi-battlefield environments. Specifically, courts vary in their ability to reduce the cases down to the specific military decision, or decisions the defendant contractor claims warrant the application of the political question doctrine and whether those military decisions implicate at least a cause, if not the proximate cause, of the plaintiff's tort case. Before discussing a proposed methodology which may bring some clarity and consistency to future cases, the disparate results currently witnessed in the courts and stemming from variations in the level and type of judicial analysis warrant discussion, as does the government's role in muddying the doctrinal waters.

III.

\section{CurRent Contractor Litigation InVOLving POLITICAL QUeSTION}

\section{A. Contract Interrogators vs. Contractor Interpreters 54}

\section{Saleh and Ibrahim}

Variations in the level and type of judicial analysis exist in two related and eventually consolidated cases, Saleh and Ibrahim. These cases typify suits filed by former Iraqi detainees against contract interrogators and interpreters who, in

53. Baker, 369 U.S. at 211 (1962).

54. In addition to the two cases chosen as examples, the reader may also wish to consider AlShimari v. CACI, No. No. 08-0827, 2009 U.S. Dist. LEXIS 29995, (E.D.Va. Mar. 18, 2009) and AlQuraishi v. Nakhla, 8:08-cv-01696-PJM (D. Md. June 30, 2008) (PACER). 
their defense, have turned to the political question doctrine. ${ }^{55}$ In both cases, the plaintiffs allege that $\mathrm{CACI}$, a government contractor that provided interrogators, and Titan, a government contractor that provided interpreters, unlawfully tortured the plaintiffs while they were detained in Iraq. ${ }^{56}$ The real significance of the cases is not the political question doctrine analysis the courts conducted but that which they failed to $\mathrm{do}^{57}$ in not considering the relationship of interrogation as a uniquely governmental function to the textual commitment prong of the Baker tests.

The two cases are also emblematic of the enhanced difficulty in applying the political question doctrine to contractors providing wartime related services. Notably, the courts are often called upon to evaluate the federal government's interests, here the military intelligence derived from battlefield interrogations and possible conflicts with those interests, despite receiving minimal input from the government itself. Indeed, minimal input overstates the U.S. Government's role in the interrogator and contractor litigation thus far. As is discussed more fully in Section IV of this Article, although these cases are directly related to the U.S. military's ability to function in Iraq and Afghanistan, the U.S. Government has yet to file a single amicus brief in them.

Ultimately, different levels of the court system dismissed the Saleh and Ibrahim suits. ${ }^{58}$ The analysis used by the district court in dismissing the suit against the contract interpreters but not the contract interrogators is striking. The court determined that "treatment of prisoners during wartime undoubtedly implicates uniquely federal interests." 59 Nonetheless, the court dismissed the suit against the interpreters but not the interrogators even though the nexus to treatment of prisoners is obviously much stronger as concerns the latter.

In terms of the Baker analysis, interpreting may not be a function that immediately suggests an issue committed to the executive branch. However, the

55. See Saleh v. Titan \& CACI, 436 F. Supp. 2d 55 (D.D.C. 2006); and Ibrahim v. Titan \& CACI (Ibrahim I), 391 F. Supp. 2d 10 (D.D.C. 2005).

56. See Saleh, 436 F. Supp. 2d 55; Ibrahim I, 391 F. Supp. 2 d 10.

57. Nor does the record supply any evidence that the contractor interrogator defendants raised the issue.

58. The district court dismissed the claims against the contract interpreters, finding that the combat activities exception to the Federal Tort Claims Act preempted the plaintiff's state tort claims. Ibrahim v. Titan, 556 F. Supp. 2d 1 (D. D.C. 2007). The district court held that the contract interpreters, unlike the contract interrogators, were under the exclusive control of the government. That the government was more closely supervising contract interpreters as opposed to the interrogators seems itself problematic. Interrogators by definition are in closer, indeed physical contact with detainees, and as discussed infra, interrogation is in an inherently governmental function. The United States Court of Appeals for the District of Columbia Circuit affirmed the dismissal of the claims against the interpreters but reversed the district court on the interrogators, dismissing the claims against them as well. Saleh v. Titan Corp., 580 F.3d 1 (D.C. Cir. 2009).

59. The word "treatment" would seem to apply more to the CACI interrogators than the Titan interpreters. Ibrahim I, 391 F. Supp. 2d. at 18. 
litigation thus far has overlooked the fact that interrogation of suspected wartime enemies is an inherently governmental function which is committed to the executive branch and yet contracted out to a non-governmental entity.

\section{Interrogation as an Inherently Governmental Function}

In the lawsuits by former detainees against contract interrogators, no mention appears to have been made that the government's use of contract interrogators violates the determination the Army made in 2000 that "the gathering and analysis" of tactical intelligence is considered "an inherently governmental function barred from private sector performance." 60 In 2003, the White House's Office of Management and Budget (OMB) reinforced the Army's determination by including in its reissued federal policy for competition for commercial activities the requirement that all governmental agencies shall "perform inherently governmental activities with government personnel."61

In 2004, the U.S. Army acknowledged both its use of contract interrogators in Iraq and that this use violated the Army's 2000 policy determination. ${ }^{62}$ The DoD has since issued instructions that detail under what circumstances contract interrogators may be used. ${ }^{63}$ Eventually, Congress also took a position on this

60. Memorandum from the Assistant Secretary for the Army for Manpower and Reserve Affairs to the Deputy Chief of Staff for the Army for Intelligence (Dec. 26, 2000), available at http://projects.publicintegrity.org/docs/wow/25-d_Intelligence.pdf (stating that "[a]t the tactical level, the intelligence function under the operational control of the Army performed by military in the operating forces is an inherently Governmental function barred from private sector performance." and "gathering and analysis of [tactical] intelligence...requires the exercise of substantial discretion in applying Government authority because intelligence at the tactical level is integral to the application of combat power by the sovereign authority."). The policy outlined in the memo did not just prohibit contract interrogators at the tactical level, but also "at the operational and strategic level, the intelligence function (less support) performed by military personnel and Federal civilian employees is a non-inherently government function that should exempted from private sector performance on the basis of risk to national security from relying on contractors to perform this function." Id.

61. Executive Office of the President, Office of Management and Budget, CIRCULAR No. A76 (Revised) (May 29, 2003). See Joel Brinkley, The Reach of War: Intelligence Collection; Army Policy Bars Interrogations by Private Contractors, N.Y. TIMES, June 12, 2004, http://query.nytimes.com/gst/fullpage.html?res=9E0DE3D81230F931 A25755C0A9629C8B63\&sec $=\&$ spon $=$ \&pagewanted $=$ all.

62. Brinkley, supra note 61 . While not revoking the 2000 policy determination, Army officials in Iraq claimed that they "retain the right to make exceptions" and that "in light of $9 / 11$ and the war on terror, the world is a different place than it was when that was written in 2000." Id. See also, David Isenberg, Dogs of War: Inherently Governmental?, UPI.COM, May 9, 2008, http://www.njscvva.org/Armed $\% 20$ Forces\%20News\%20PDFs/200805/2008\%2005\%2009\%20$\% 20$ Dogs $\% 20$ of $\% 20$ War.pdf.

63. U.S. DEPT'T OF DEFENSE, INSTR. 1100.22, GUIDANCE FOR DETERMINING WORKFORCE MIX (7 Sep. 2006) [hereinafter DODI]. The DODI provides that if interrogations are to be "performed in hostile areas where security necessary for DoD civilian performance cannot be provided" then the interrogation position is considered a function which "cannot be legally 
question in an interim version of 2009 National Defense Authorization Act (NDAA) which banned the use of contract interrogators in combat zones. ${ }^{64}$ This led to the Executive Office of the President issuing a statement that

[T]he Administration strongly objects to requirements that would prevent the Department of Defense from conducting lawful interrogations in the most effective manner by restricting the process solely to government personnel; in some cases, a contract interrogator may possess the best combination of skills to obtain the needed information. Such a provision would unduly limit the United States' ability to obtain intelligence needed to protect Americans from attack. ${ }^{65}$

Congress subsequently agreed to an amendment to the NDAA that changed the prohibition against the use of contract interrogators to a non-binding "sense of Congress." 66 By the summer of 2009 , the DoD had issued an interim final

contracted and shall be designated for performance by government personnel." DODI at ๆ 6.1.2 and Enclosure 2 If $\mathrm{E}$ 2.1.6.2. But "in areas where adequate security is available and is expected to continue, properly trained and cleared contractors may be used to draft interrogation plans for government approval and conduct government approved interrogations." Enclosure 2, \2.1.6.2. The DODI claims that "[r]esponsibility for [detainee] handling as well as decisions concerning how they are treated cannot be transferred to private sector contractors who are beyond the reach of government controls." Id. at I 2.1.6. Given that the government has criminal jurisdiction over contractors both through the Military Extraterritorial Jurisdiction Act (18 U.S.C. $\S 3261$ ) and more recently, the Uniform Code of Justice (10 U.S.C. $\$ 802(a)(10)$ ), it does not seem that contractors are beyond the reach of government controls. Although presumably not the intent, given that such controls exist, the DODI would seem to allow private sector contractors to be responsible for detainee handling and treatment. Where the DODI at least attempts to restrict the use of contract interrogators due to battlefield interrogation's inherently government function status, the DODI states that "properly trained and cleared contractors may be used as linguists, interpreters, report writers, etc...." Id. at 72.1 .6 .2 .

64. S. 3001, 110th Cong. $\S 1036$ (2008) (as reported by the S. Comm. On Armed Services, May 12, 2008); H.R. $5658 \S 1077,110$ th Cong. The bill required that, by one year after the enactment of the FY 2009 NDAA:

The DOD manpower mix criteria [discussed in the DODI, supra note 62, at $\$ 6.1$ ] and the [Federal Acquisition Regulation] be revised to provide that: (1) the interrogation of prisoners of war and other detainees is an inherently governmental function that cannot be transferred to private contractors who are beyond the reach of controls applicable to government personnel; and (2) properly trained and cleared contractors may be used as linguists, interpreters, report writers, and information technology technicians if their work is properly reviewed by appropriate government personnel.

65. Executive Office of the President, Statement of Administration Policy S.3001-National Defense Authorization Act for FY 2009 (Sep. 9, 2008), http://www.fas.org/ irp/news/2008/09/wh090908.pdf (last visited Dec. 28, 2009).

66. National Defense Authorization Act for Fiscal Year 2009, PUB. L. NO. 100-417 $\$ 1057$ (2008). The sense of Congress is titled "Interrogation of Detainees by Contractor Personnel" and states that:

It is the sense of Congress that - (1) the interrogation of enemy prisoners of war, civilian internees, retained persons, other detainees, terrorists, and criminals when captured, transferred, confined, or detained during or in the aftermath of hostilities is an inherently governmental function and cannot appropriately be transferred to private sector contractors; (2) not later than one year after the date of the enactment of this Act, the Secretary of Defense should develop the resources needed to ensure that interrogations described in paragraph (1) can be conducted by government personnel 
rule that purported to "procedurally close existing gaps in the oversight of Private Security Contractors, ensur[ing] compliance with laws and regulations pertaining to Inherently Governmental functions . . ."67 However, this rule is limited to contractors performing private security functions, which the rule defines as engaging in guarding of "personnel, facilities, designated sites, or property" and "any other activity for which personnel are required to carry weapons for the performance of their duties."68 The DoD's efforts did not appear to satisfy Congress, which renewed its efforts to bar the use of contractors in interrogating detainees, this time through language in the 2010 NDAA. ${ }^{69}$ This, in turn, prompted similar opposition from the White House, despite the change in Presidential administrations which occurred between the 2009 and 2010 NDAA versions. $^{70}$

The Army's determination that interrogation is an inherently governmental function, at a minimum for the time period at issue in the litigation, would seem to aid the contract interrogators' political question doctrine argument. In fact, the Army's determination coupled with the White House's OMB policy should have been considered under Baker as "textual commitment" of interrogation to the executive branch. That the Army violated its own determination and thereby triggered Congressional involvement only strengthens the argument for the doctrine's applicability. Specifically, the contract interrogators would appear to be able to argue that for the judiciary to speak on an issue which both the executive and legislative branches have spoken would constitute the "lack of respect due coordinate branches of government," which Baker cautioned courts to avoid. ${ }^{71}$ Additionally, for the courts to address the use of contract interrogators when the executive branch has said one thing (while doing

and not by private sector contractors; and (3) properly trained and cleared contractors may appropriately be used as linguists, interpreters, report writers, information technology technicians, and other employees filling ancillary positions, if the private sector contractors are subject to the same rules, procedures, policies, and laws pertaining to detainee operations and interrogations that govern the execution of these positions by government personnel.

67. Summary, Private Security Contractors (PSCs) Operating in Contingency Operations, 74 FED. REG. 136 (July 17, 2009) (to be codified at 32 C.F.R. pt. 159).

68. Id. at $\$ 159.3$.

69. Karen DeYoung, Administration Bridles at Bar on Contractors, WASH. POST., July 16, 2009 , at A2 (referring to a provision in the 2010 defense funding bill which would list interrogation as an inherently governmental function and quoting one of provisions supporters, Senator Carl Levin, as saying that interrogations "cannot be transferred to contractor personnel.").

70. Id. (quoting the White House as expressing "serious concerns" about Congress' attempt to bar the use of contract interrogators which, according to one administration official "could prevent U.S. Forces from conducting lawful interrogations in the most effective manner). Interestingly, the provision provides an exception for the use of contract interpreters which prompted an administration official to state than any distinction between contract interpreters and contract interrogators is "artificial." $I d$.

71. Baker, 369 U.S. at 217 (1962) 
another) and Congress has also spoken would embody the "multifarious pronouncements by various departments on one question," which Baker forbids. ${ }^{72}$

\section{B. Insurgent Attacks Compared to Vehicle and Aircraft Crashes}

The strained application of the political question doctrine to wartime contractor activities is perhaps most glaring when cases involving insurgent attacks against contractors are compared to cases involving contractor vehicle and aircraft crashes in Iraq and Afghanistan. Similar to the interpreter/interrogator cases, the comparative outcomes in the insurgent attack and vehicle/aircraft crash cases often appear counterintuitive and inconsistent.

\section{Insurgent Attacks}

The Fisher, Lane, and Smith-Idol line of federal cases from Texas provide contrasting views regarding the application of the political question doctrine to contractor employee suits stemming from insurgent attacks. ${ }^{73}$ The plaintiffs in each of these cases were former truck drivers (or their representatives) who worked for Kellogg Brown and Root (KBR) in Iraq and were injured or killed when insurgents attacked their logistics convoys in April, 2004. ${ }^{74} \mathrm{KBR}$ operated the convoys pursuant to a contract with the Army to provide essential services and personnel to support its military operations in Iraq. ${ }^{75}$

The plaintiffs in each suit claimed that during KBR's efforts to hire drivers, it committed fraud and deceit by intentionally misrepresenting the dangers in Iraq. ${ }^{76}$ The plaintiffs also alleged that KBR had control over when, where, and how to deploy the logistics convoys, and the negligent manner in which it did so led to their physical injuries and/or death. ${ }^{77}$

72. Id.

73. At the district court level, see Fischer v. Halliburton, 454 F. Supp. 2d 637 (S.D. Tex. 2005); Lane v. Halliburton, No. H-06-1971, 2006 WL 2396249 (S.D. Tex. Sept. 26, 2006); and Smith-Idol v. Halliburton, No. H-06-1 168, 2006 WL 2927685 (S.D. Tex. Oct. 11, 2006). At the appellate level, see Lane v. Halliburton (Lane Appeal), 529 F.3d 548 (5th Cir. 2008), the consolidated appeal. Although not part of the Fisher, Lane, and Smith-Idol series, Woodson involved "significantly similar" facts, arguments, and evidence, the difference essentially being that the plaintiff was injured by an insurgent attack of a Halliburton logistics convoy on a different date and at a different location in Iraq. Woodson v. Halliburton, No. H-06-2107 2006 WL 2796228 (S.D. Tex. Sept. 28, 2006) (accordingly, the district court dismissed Woodson on the same political question grounds as in Fisher, Lane, and Smith (dol).

74. Fischer v. Halliburton, 454 F. Supp. 2d 637 (S.D. Tex. 2005); Lane v. Halliburton, No.061971, 2006 WL 2396249 (S.D. Tex. Sept. 26, 2006); Smith-Idol v. Halliburton, No. 06-1168, 2006 WL 2927685 (S.D. Tex. Oct. 11, 2006).

75. Fisher, 454 F. Supp. 2d at 638.

76. Id. at 639; Lane, 2006 WL 2396249, at *1; Smith-Idol, 2006 WL 2927685, at *1.

77. Fisher, 454 F. Supp. 2d at 639. 
The defendants moved to dismiss the plaintiffs' claims on, among other grounds, the political question doctrine. KBR argued that the Army, not KBR, controlled the deployment and protection of logistics convoys and that those decisions that KBR did make in this regard were "so interwoven with Army decisions, the court lacks jurisdiction . . .under the political question doctrine."78 The plaintiffs replied that the political question doctrine did not apply because their complaint "involves claims by civilians, not military personnel, questions [KBR's] actions as civilian contractors, not the Army's execution of a mission. . " and alleged that [KBR], not the Army, directed the convoys in question, "making inquiry into military decisions and rules of engagement unnecessary."79

The district court dismissed all three cases on political question grounds, finding that the nature of the suit implicated three of the Baker tests. ${ }^{80}$ The court stated that Baker requires a determination of "whether a political question will arise during the course of the trial, not whether it is evident from the face of

78. Id. Specifically, KBR argued that:

The Complaint necessarily raises issues regarding the conduct of military operations during armed conflict that are committed to the discretion of the political branches of government. Further, no judicially manageable standards exist to evaluate the propriety of the issues here, including: whether the military adequately considered security concerns and supply needs when it planned, scheduled, and deployed the fuel supply convoy; whether it assigned force protection sufficient to deal with potential threats along the convoy route it selected; whether it properly evaluated the level of threats present on that route; and whether it properly trained, prepared, and equipped the military personnel providing force protection to the convoy.

Motion to Dismiss at 36, Lane v. Halliburton, No. H-06-1971 (S.D. Tex. Sept. 26, 2006); Motion to Dismiss at 29-30, Smith-Idol v. Halliburton, No. H-06-1168 (S.D.Tex. Oct. 11, 2006). The motion to dismiss in Fisher was sealed.

79. Fisher, 454 F. Supp. $2 d$ at 641 . The plaintiffs argued that the very language of the LOGCAP contract required KBR to "manage and direct their own convoys." Id. at 642 . As well, they quoted from an Army publication entitled "Contractors on the Battlefield" to support the proposition that military "[c]ommanders do not have direct control over contractors or their employees (employees are not the same as government employees); only contractors manage, supervise, and give directions to their employees." Id.

80. Id. at 639-44. Under the first Baker test, textual constitutional commitment to a coordinate branch, the court held that "it cannot try a case set on a battlefield during war-time without an impermissible intrusion into powers expressly granted to the Executive by the Constitution." Id. at 641. The court also found the second Baker test, lack of judicially discoverable and manageable standards "equally implicated." Id. While the plaintiffs contended that their focus was on KBR's actions and not those of the Army, the court held it would "inexorably be drawn" to distinguish and examine decisions by both KBR and the Army, a task for which the judiciary lacks "discoverable and meaningful standards." Id. at 644 . Applying the third test, nonjudicial policy determination and lack of respect, the court contended that plaintiffs ask it to determine why the convoy attack happened. $I d$. at $641-44$. To answer this question would require, in the judges' estimation, delving into the wisdom of using contractors on the battlefield at all as well as using them on the specific convoys at issue. Id. at 644. The court labeled attempts to resolve the issue as tantamount to examining the policies of the Executive Branch during wartime, "a step the court declines to take." Id. 
the complaint." recall convoys, the court would still need to determine whether the Army could or should have countermanded that order." 82 In the end, the court concluded that it would have to substitute its judgment for that of the Army to be able to hear the case. ${ }^{83}$

In response to the lower court's ruling, the plaintiffs appealed to the Fifth Circuit and attempted to frame the issue as a damages claim by civilian truck drivers employed by a private contractor that was "providing non-combat logistical support services in Iraq." 84 They claimed that "the conflict in Iraq happens to be a politically charged matter, but that does not make this case nonjusticiable under the political question doctrine." 85 Furthermore, the appellants contended that the district court "simply saw Iraq and stopped." 86

In contrast, KBR asked the appellate court "[w]hether [a]ppellants" damages suits, if adjudicated, would require the district court to second-guess U.S. military policies and decisions that resulted in the convoy incidents involved in these appeals and relate to the conduct of the ongoing war in Iraq, and thus are barred by the political question doctrine." 87 They argued that "the Baker [tests] demonstrate that adjudication of appellant's claims would require resolution of non-justiciable political questions." 88 Political questions were, KBR alleged, inherent in both the fraud and tort claims and "could not be avoided." 89 Moreover, they stressed that the "appellants' claims must be

81. Id. at 641 (quoting Occidental of Umm Al Qaywayn v. Certain Cargo of Petroleum (Occidental), 577 F.2d 1196, 1202 (5th Cir. 1978)).

82. Id. at 643 . The court added that that "[ $t]$ he evidence shows overwhelmingly that the Army was an integral part of any decision to deploy and protect convoys." Id.

83. Id. The court listed examples of areas in which it believed it would have to impermissibly substitute its judgment for that of the Army, including "determining what intelligence the Army gave to KBR about the route, whether that intelligence was sufficient, what forces were deployed with the convoys, whether they were sufficient, and whether they performed properly." Id.

84. Appellants' Brief at 2, Lane v. Halliburton, 529 F.3d 548 (5th Cir. 2008) (No. 06-0874).

85. Id. at 21

86. Id.

87. Appellees' Brief at 1, Lane, 529 F.3d 548.

88. Id. at 32 . KBR essentially repeated their arguments from the district court that:

[1] [T] he Constitution textually commits to the political branches consideration of the military, national security, and foreign policy decisions and issues that adjudication of appellants claims would entail;

[2]There are no judicially discoverable manageable standards for resolving the military, national security, and foreign affairs decisions and issues that adjudication of appellants claims would require; and

[3] [A]djudication of appellant's claims would require policy determinations that exceed judicial discretion and demonstrate lack of respect for the political branches.

Id. at 32-47.

89. Id . at 36,42 . 
analyzed as they would be tried, not as they are pleaded, to determine whether they present political questions." 90

Answering these arguments, the Fifth Circuit

[A]cknowledge[d] that the [p]laintiffs' claims are set against the backdrop of United States military action in Iraq. Thus, these cases are at the very least in sight of an arena in which the political question doctrine has served one of its most important and traditional functions - precluding judicial review of the decisions made by the Executive during war time. ${ }^{91}$

The court noted that the days in which "the Supreme Court would categorically remove disputes implicating the "conduct of foreign relations" from judicial purview" 92 were long past and referenced the Baker court's admonition that "it is error to suppose that every case or controversy which touches foreign relations lies beyond judicial cognizance." 93

Moreover, the appellate court disagreed with the lower court's application of the Baker tests. According to the Fifth Circuit, "the first Baker [test] is primarily concerned with direct actions taken by a coordinate branch of the federal government." KBR, by invoking the textual commitment test, therefore faced a "double burden." 94 Under this burden, "[f]irst, [KBR] must demonstrate that the claims against it will require reexamination of a decision by the military. Then it must demonstrate the military decision at issue is . . . insulated from judicial review." 95 With little to no explanation of how KBR failed to meet that double burden, the court then claimed that "there is no textual commitment to the coordinate branches of the authority to adjudicate the merits of the Plaintiff's claims against KBR for breach of its duties." 96

The court was more sympathetic to the district court's analysis of the

90. Id. at 28. The Fifth Circuit supports the appellee's position in this regard. See Occidental of Umm Al Qaywayn v. Certain Cargo of Petroleum, 577 F.2d 1196, 1202 (5th Cir. 1978)) (stating that the court considers the complaint "as it would be tried, to determine whether a political question will emerge").

91. Lane, 529 F.3d at 558.

92. Id. (citing Oetjen v. Cent. Leather Co., 246 U.S. 297, 302 (1918)).

93. Id. (citing Baker v. Carr, 369 U.S. 186, 211 (1962)).

94. Id. at 560 (citing McMahon v. Presidential Airways, 502 F.3d 1331, 1359 (9th Cir. 2007)).

95. Id. at 560 (quoting McMahon, 502 F.3d at 1359-60) (emphasis in original).

96. Id. The Court of Appeals claimed that it would be an "extraordinary occasion, indeed, when the political branches delve into matters of tort-based compensation" citing the September 11 Victim Compensation Fund as one such occasion. Id. The Court made this point in support of its claim that there is "no textual commitment to the coordinate branches of the authority to adjudicate the merits of the Plaintiffs' claims against KBR." Yet, the U.S. Army Claims Service adjudicated the merits of Mr. Saleh's tort claim. A military investigation concluded that Mr. Saleh was not interrogated or abused, but should not have been at Abu Ghraib in the first place. As a result, the Army awarded Saleh $\$ 5000$ for his unnecessary internment at Abu Ghraib. Saleh v. Titan Corp., 580 F.3d 1, 3 (D.C. Cir. 2009). As a result, the executive branch's involvement in tort-based compensation may not be that out of the ordinary, rendering the Fifth Circuit's reliance on that point for its political question doctrine analysis misplaced. 
second Baker test, lack of judicially manageable standards. ${ }^{97}$ It claimed that this test was "arguably the most critical factor" in Lane "because at least some of the considerations would drag a court into a consideration of what constituted adequate force protection for the convoys." 98 The court stated that the district court may have to "adjust traditional tort standards to account for the "less than hospitable environment' in which KBR operated" but that in of itself is not a justiciability issue under Baker. ${ }^{99}$

And, finally, the court made relatively short work of the district court's determination that under the third Baker test the claims would "necessarily entail a judicial pronouncement as to the wisdom of the military's use of civilian contractors in a war zone." 100 In the Fifth Circuit's view, the district court would be "asked to judge KBR's policies and actions, not those of the military or executive branch."101 Indeed, the court surmised that "the application of traditional tort standards may permit the district court to navigate through this politically significant case without confronting a political question." 102

Ultimately, the court was not persuaded that the political question doctrine applied and, thus, concluded that the judiciary could properly hear the plaintiffs' claims. ${ }^{103}$ However, in remanding the case, the court explained that it did not "mean to indicate the district court is bound to continue its efforts to extricate the [p]laintiff's claims from the military decision indefinitely." 104

That insurgent attacks on U.S. logistics convoys in Iraq did not, at least in Lane, result in the application of the political question doctrine may be surprising to some. ${ }^{105}$ According to the doctrine, courts should be more likely

97. Lane, 529 F.3d at 556. In a footnote to its analysis of the second Baker test, the court stated that the plaintiffs' claims did not "directly challenge any government or Executive action" and were "far enough removed from the type of textual commitment envisioned by Baker and its progeny to shift [the court's] primary analysis to the second factor." Id.

98. Id.

99. Id. at 563 (referring to McMahon, 502 F.3d at 1363-64).

100. Id. (referring to McMahon, 502 F.3d at 1364).

101. Lane v. Halliburton (Lane Appeal), 529 F.3d 548, 563 (5th Cir. 2008).

102. Id. (emphasis in original).

103. Since the cases returned to the district court in July 2007 , there have been over 200 hundred additional docket entries, although the nature of the filings is unclear as most are sealed. See docket entries dated between July 7, 2007 and the present, Fisher v. Halliburton, 454 F. Supp. 2d 637 (S.D. Tex. 2005) (No. H-05-1731). Presumably Halliburton has, or will, renew its motion to dismiss on political question grounds, so the cases may return to the Fifth Circuit.

104. Lane Appeal, 529 F.3d at 556.

105. But see Smith v. Halliburton, No. H-06-0462, 2006 WL 2521326 (S.D. Tex. Aug. 30, 2006) (holding that the political question doctrine prevented the court from hearing a case brought by the representatives of a KBR employee killed when a suicide bomber detonated an explosive in a dining facility on a U.S. military base in Iraq). The court determined that the military and not KBR was responsible for security or force protection functions: "were the case to proceed, this court would have to second-guess the decisions of the United States military, even though the suit is ostensibly against only military contractors." Id. 
to dismiss a case on political question grounds if they believe that the military is in actual control of the specific contractor actions relevant to an element of the tort suit. In practice, however, the outcome of the political question analysis appears to depend on the decision making level the court considers when assessing the suit. If assessing the suit at a macro decision making level, the foreign affairs and Commander-in-Chief powers of the executive branch inherent in the decision to invade Iraq and to rely on contractors would be relevant. At the other end of the spectrum, at the micro decision making level, the inquiry would focus on whether the government or the contractor controlled a logistics convoy's movement from point $A$ to point $B$ and under what conditions it did so. As the following cases demonstrate, while the micro level approach brings the specificity and detail the macro view lacks, trying to parse out the level and type of control over a logistics convoy as a way to determine the applicability of the political question yields outcomes no more coherent or predictable.

\section{Convoy Accidents}

In Whitaker ${ }^{106}$ and Carmichael, ${ }^{107}$ Georgia district courts found that the political question doctrine precluded them from considering the military's level of control over convoy operations in Iraq. Yet, in neither decision did the courts link the military's control to a cause of the accident, proximate or otherwise. It is also not clear what specific unreviewable military decision the courts believed were inextricably linked to the cases. Here again, the judiciary's lack of analytical clarity on these points further complicates the application of the doctrine.

\section{a. Whitaker}

In Whitaker, a U.S. Army Soldier was killed in Iraq in April 2004 while escorting a KBR logistics convoy. ${ }^{108}$ After a KBR vehicle drove off a bridge, Private First Class Whitaker stopped his vehicle which was then struck by the KBR vehicle following it, knocking Whitaker's vehicle near the edge of the bridge. ${ }^{109}$ While trying to escape this precarious position, Whitaker fell off the bridge and drowned. ${ }^{110}$ Whitaker's parents filed suit, labeling the case a "garden variety road wreck" for which they claimed judicially discoverable and

106. Whitaker v. KBR, 444 F. Supp. 2d 1277 (M.D. Ga. 2006).

107. Carmichael v. KBR (Carmichael I), 450 F. Supp. 2d 1373 (N.D. Ala. 2006), aff'd, Carmichael v. KBR (Carmichael Appeal), 572 F.3d 1271 (9th Cir. 2009). While this section refers to aspects of the Carmichael appeal, the focus is on the district court's analysis.

108. Carmichael Appeal, 572 F.3d at 1278.

109. Id.

110. Id. 
manageable standards existed. ${ }^{11}$

In reply, KBR moved to dismiss on political question grounds. ${ }^{112}$ The U.S. District Court for the Middle District of Georgia granted KBR's motion, holding that the convoy operation was "planned by the military, which determined the placement of vehicles in the convoy, the speed of the convoy, and the distance between vehicles in the convoy."113 The court stated that the circumstances, while involving no insurgent activity, were dramatically different "from driving on an interstate highway or country road" in the United States and that " $[\mathrm{t}] \mathrm{he}$ question here is not just what a reasonable driver would do-it is what a reasonable driver in a combat zone, subject to military regulations and orders, would do." 114

In spite of the court's clear rejection of the claim, it never explained exactly how the circumstances differed from a "garden variety road wreck," nor did it discuss how PFC Whitaker being subject to military regulations and orders related to his particular accident. Similarly, while all of Iraq may generally be considered a combat zone, unless Whitaker or others in the convoy took different actions on the Iraqi bridge than they would have in comparatively safe Kuwait or even the United States, then just being in a combat zone bears little on causation. The court's reliance on the fact that the military planned the convoy also seems misplaced, unless the manner in which the military planned the convoy was a significant factor in the first vehicle going off the bridge, PFC Whitaker's decision to stop his vehicle, or the vehicle behind PFC Whitaker's striking his.

\section{b. Carmichael}

In May 2004, Sergeant (SGT) Keith Carmichael was a military escort and passenger in a KBR tractor-trailer in Iraq when a contractor employee lost control of the vehicle and plummeted into a ravine. ${ }^{115}$ Carmichael suffered severe injuries and his wife filed suit against KBR on his behalf. ${ }^{116}$ The District Court for the Northern District of Georgia initially denied a motion to dismiss

111. Id. at 1282 .

112. See Whitaker v. KBR, 444 F. Supp. 2d 1277 (M.D. Ga. 2006).

113. Id. at 1282 .

114. Id. The district court likened the political question analysis in Whitaker to a suit filed by Turkish sailors after missiles fired by a U.S. ship during a training exercise injured them. As in Whitaker, the court found that there were no judicially discoverable and manageable standards, that a decision on the merits would require the court to make policy decisions "of a kind appropriately reserved for military discretion," and that "adjudicating the case would express a lack of respect for the political branches of the government." Id. at 1280-81 (quoting Aktepe v. United States, 105 F.3d 1400, 1403 (11th Cir. 1997)).

115. Carmichael I, 450 F. Supp. 2d at 1374.

116. Id. 
on political question grounds, stating its disagreement with Whitaker's reasoning. ${ }^{117}$ Yet, after two years of discovery, the court dismissed the case on essentially the same grounds, providing no more clarity than the court did in Whitaker. ${ }^{118}$ While the plaintiffs presented evidence that "the convoy was a non-combat operation and that each individual driver retained discretion to vary his speed or course within the convoy to operate his vehicle safely," 19 the court was persuaded by KBR's evidence that:

[T] he army did in fact control every aspect of the organization, planning and execution of the convoy in question. The KBR drivers were trained according to military standards, the military convoy commander retained responsibility for inspecting both drivers and their equipment before commencing the convoy, and the route and speed of the convoy were set by the military and not by the civilian drivers. Therefore, the conduct of the military and its handling of supply convoys used to support military operations would necessarily be questioned were this case allowed to go forward. ${ }^{120}$

When the court originally denied KBR's motion, its inquiry focused on the actions of the KBR employee driving the tractor-trailer Carmichael occupied. ${ }^{121}$ Specifically, the court hypothesized that "it is conceivable that at the time of the accident [the contractor employee] was driving the truck within the speed limit set by the military yet in a manner that was negligent in some other respect."122 The court did not revisit its own hypothesis when later dismissing the case despite evidence the plaintiffs presented concerning individual driver options on speed and course and the fact that only Carmichael's vehicle veered into a ravine. The court itself initially claimed that "[i]f there is no showing that resolution of a survivor's negligence claims would require the [c]ourt's reexamination of any decision made by the U.S. military, the case presents no political question, and therefore the [c]ourt has jurisdiction over the case."123 In later dismissing the case, the court failed to state what military decision the court would have to examine to resolve the inquiry concerning a vehicle driving off the road. ${ }^{124}$ Though the military makes numerous decisions and the incident happened in Iraq, unless those decisions and the situs of the incident influence the tort elements in some way, they do not seem legally relevant and certainly

117. Id. at 1377. In its initial ruling, the court stated that it respectfully disagreed with, and would not follow, the middle district's ruling in Whitaker. Id.

118. Carmichael v. KBR (Carmichael II), 564 F.Supp.2d 1363 (N.D. Ga. 2008).

119. Id. at 1368 .

120. Id.

121. Id. at 1376 .

122. Id.

123. Id. at 1367 .

124. The Eleventh Circuit decision is similarly imprecise. Neither court ever links any aspect of the road conditions to the accident, and insurgent activity was not involved. Instead, the court discusses how those "difficult military conditions" required "delicately-calibrated decisions based on military judgment, experience, and intelligence-gathering." Id. 
not dispositive of a justiciability issue such as the political question doctrine. ${ }^{125}$

\section{c. Potts}

Indeed, in Potts, where combat circumstances in Iraq played a role in the accident, the court found that the political question doctrine did not apply. Mr. Potts, a contract employee who worked for Worldwide Network Services, Inc., filed suit ${ }^{126}$ against Dyncorp for injuries he suffered as a result of a car accident while a passenger of a Dyncorp driver in Iraq. ${ }^{127}$ Traveling at a high rate of speed, the driver swerved to avoid what he thought may be an improvised explosive device (IED). ${ }^{128}$ The vehicle flipped, burst into flames, and severely injured Potts. ${ }^{129}$ After Potts filed suit, the court denied Dyncorp's attempt to amend its answer to assert the political question doctrine, holding that "Dyncorp mischaracterizes the issue by implying that the court would have to assess United States military or State Department policies to determine whether Dyncorp was negligent." 130 The court claimed that the plaintiffs correctly summarized the case as involving a "civilian contract to provide non-military security services to non-military personnel for the purpose of delivering nonmilitary supplies."131 It was, therefore, "able to assess whether the private contractor was negligent or wanton, even when performing services in a war zone. The fact that the car accident at issue occurred in a war zone does not automatically result in a lack of judicially discoverable and manageable standards for resolving the issue." 132

The court's focus in Potts on the macro level of Dyncorp's contract with the government dictated the outcome of the political question analysis. That focus came at the expense of considering the specific cause of the accident, an attempt to avoid what was feared to be an IED. Where there is a nexus between

125. The plaintiff-appellants unsuccessfully made a similar argument to the Eleventh Circuit in Carmichael. They alleged that Mr. Irvin's was the only vehicle in a 15 vehicle convoy that crashed, suggesting negligence by Irvin and not a treacherous roadway. Carmichael Appeal, 572 F.3d 1271, 1278,1285 (9th Cir. 2009). The court labeled this argument "much too facile." Id. The plaintiffappellants also argued that Mr. Irvin was "responsible for steering the vehicle and controlling its speed" which the court deemed "little more than a play on the words 'control' and 'responsibility." Id. at 1284 .

126. Potts v. DynCorp Int'l, 465 F. Supp. 2d 1245 (M.D. Ala. 2006).

127. See id. Dyncorp operated in Iraq pursuant to a contract with the U.S. government for an "oil for food" project. Id. at 1248 .

128. For general information on IEDs, see CONGRESSIONAL RESEARCH SERVICE, Pub. No. RS22330, IMPROVISED EXPLOSIVE DEVICES (IEDS) IN IRAQ AND AFGHANISTAN: EFFECTS AND COUNTERMEASURES (2006).

129. Potts, 465 F. Supp. 2d at 1248.

130. Id. at 1250 .

131. Id.

132. Id. at 1253 . 
the proximate cause of a tort action and a uniquely combat operation circumstance like IEDs, the potential for the political question doctrine to apply should exist, but, as discussed above, the court in Potts thought otherwise. Without suggesting that the court ignore Dyncorp's contract with the government, justice may have been better served by focusing on how and from whom Dyncorp drivers learned of IED threats and received training on how to respond. Such evidence, or lack thereof, would be more directly relevant and more helpful to the trier of fact. For example, evidence that the military did, or did not, brief Dyncorp drivers about the IED threat or provided counter IED driving training would influence whether the military would be implicated in the judicial determination as to whether the driver's response and reaction to what he thought was an IED were reasonable. As it stands, it remains unclear just how the court will develop judicial standards to evaluate the threat of IEDs, determine whether the driver's belief that the object in the road was an IED, and evaluate if his subsequent reactions were reasonable.

\section{The Real Inquiry}

Not all courts have shared these struggles in applying the political question doctrine to wartime contractor tort litigation that have been presented above. In Lessin ${ }^{133}$ and McMahon, ${ }^{134}$ both a district and an appellate court provide useful examples of how to resolve political question disputes involving government contractors with greater analytical rigor and clarity.

The Lessin case concerns a U.S. Army soldier injured while providing a military escort to a KBR logistics convoy in Iraq. ${ }^{135}$ While en route from Iraq to Kuwait, one of KBR's trucks stopped due to a malfunctioning loading ramp. ${ }^{136}$ When Lessin attempted to help the driver of the truck, the ramp struck him in the head, severely injuring him as a result. ${ }^{137}$ Lessin filed suit against $\mathrm{KBR}$, which moved to dismiss the complaint based on the political question doctrine. ${ }^{138}$

133. Lessin v. KBR, No. H-05-01853, 2006 WL 3940556 (S.D. Tex. June 12, 2006).

134. McMahon v. Presidential Airways, 502 F.3d 1331 (9th Cir. 2007). Interestingly, the court that decided McMahon is the same court that later decided Carmichael, the Eleventh Circuit. Nonetheless, the two cases are difficult to reconcile. Both involve crashes, in McMahon of an airplane in Afghanistan and in Carmichael a vehicle in Iraq, which seem to lack a nexus to combat operations. In McMahon, the Eleventh Circuit held that the political question doctrine did not apply, but in Carmichael it found that it did. One distinction that may have informed the court's decision was the record before the court when it heard the cases. McMahon reached the court of appeals with minimal information while Carmichael arrived after several years of discovery.

135. Lessin, 2006 WL 3940556, at *1.

136. Id.

137. Id.

138. Id. at *2. KBR argued that the case involved the first four Baker tests. Id. at *3. Under the first Baker test, KBR asserted that Lessin's claims "necessarily involve issues committed to the 
The court disagreed, holding that KBR failed to demonstrate that "military decision-making or policy would be a necessary inquiry, inseparable from the claims asserted."139 Instead, the court determined that Lessin's claims of KBR's negligence were "not certain to implicate such topics, or any others that are committed to the political branches. The incident at issue in this case was, essentially, a traffic accident, involving a commercial truck alleged to have been negligently maintained, as well as a civilian truck driver who was allegedly negligent in operating the truck and insufficiently trained." 140

In similar fashion, the Eleventh Circuit in McMahon distinguished the defendant's assertion of the political question doctrine's applicability from the plaintiffs' claims and the evidence required to prove those claims. ${ }^{141}$ On November 27, 2004, a contractor owned and operated airplane crashed into the side of a mountain in Afghanistan killing all aboard, including three active duty members of the U.S. Army. ${ }^{142}$ Relatives of the soldiers filed a wrongful death suit against the contractor, Presidential Airways. ${ }^{143}$ In turn, Presidential Airways filed a motion to dismiss the suit based on the political question doctrine arguing that "were this lawsuit to proceed, [the district court] would inevitably be asked to resolve a number of military "policy choices and value determinations," such as why the DoD specified, among other things, the aircraft type, the aircraft equipment, and the pilot qualifications and approved

executive branch, including military decision-making and the conduct of military operations." Id. KBR argued that "because Lessin was injured while attempting to assist the malfunctioning convoy truck, adjudicating Plaintiffs' claims will require an inquiry into whether Lessin was trained properly on civilian equipment, whether he complied with applicable military regulations and directives regarding civilian contractor convoys, and whether these military regulations were adequate to prevent his injury." Id. KBR attempted to bolster its argument that the Plaintiffs' allegations would involve military decision making by claiming that following an investigation of Lessin's injury, the military purportedly developed new procedures limiting military personnel from assisting civilian convoys. Id. For the second Baker test, KBR contended that Lessin's claims were not susceptible to resolution by judicially discoverable standards. Id. at 3-4. KBR's argument of how the second Baker test applied was that the court was unable to develop standards to access the reasonableness of the military's judgment in "permitting the civilian truck at issue to be a part of the military convoy... for the military to stop the convoy in a combat zone to attempt to repair the truck, whether it was appropriate for Lessin to assist in the truck's repair, and whether the military exercised an appropriate level of maintenance over the truck." $I d$. KBR concluded its political question argument by arguing that the third and fourth Baker tests were also implicated as the case, in KBR's view, would "require the Court to undertake an initial policy decision concerning the interaction between military personnel and civilian contractors in a combat zone, and to express a lack of respect due to the coordinate branches of government that oversee such war efforts." Id. at 4 .

139. Id. The court acknowledged that where the military's strategy, decision-making, or orders are necessarily bound up with the claims asserted in a case, the political question doctrine is implicated, and the case is inappropriate for judicial inquiry. Id.

140. Id. at 4-5.

141. McMahon v. Presidential Airways, 502 F.3d 1331 (9th Cir. 2007).

142. Id. at 1336 .

143. Id. 
the route structures of the acknowledged DoD mission. . ."144 Presidential claimed that these are "military choices and value determinations that are 'constitutionally committed for resolution to the legislative or executive branches."'145

The district court denied the motion and Presidential filed an interlocutory appeal with the Eleventh Circuit. ${ }^{146}$ At this point, the only evidence before both courts was the complaint, the contract between Presidential and DoD to provide air transport, and the statement of work for that contract. ${ }^{147}$ The court of appeals affirmed the lower court's judgment, ruling that Presidential did not even satisfy the threshold requirement of the first Baker factor - a demonstration that the case would "require examination of any decision made by the military."148 While the court acknowledged that "[t]he military chose the start and the end points of the flights, and when the flights would be flown. . [i]t was not evident" the court continued "that [the plaintiffs'] allegations relate to any of these discrete areas of military responsibility." 149

Presidential, the Eleventh Circuit held, "also failed to show that the case will require the application of judicially unmanageable standards." 150 The court conceded that "flying over Afghanistan during wartime is different from flying over Kansas on a sunny day," but added "that does not render the suit non justiciable." 151 In the court's view, "[a]s in any tort suit involving a plane crash,

144. Motion to Dismiss at 19, McMahon v. Presidential Airways, No. 05-1002, (M.D. Fla. Dec. $15,2005)$. While the Eleventh Circuit was not persuaded by Presidential Airways' argument in McMahon, the court accepted what seems a similar argument in Carmichael when dealing with the military's role in convoy operations. See Carmichael Appeal, 572 F.3d 1271 (9th Cir. 2009).

145. Motion to Dismiss at 19, McMahon v. Presidential Airways, No. 05-1002 (M.D. Fla. Dec. $15,2005)$.

146. McMahon v. Presidential Airways at $\mathbf{1 3 3 6 .}$

147. Id. at 1360. On appeal, Presidential unsuccessfully argued that in addition to the complaint, contract and statement of work, the court should also consider declarations from Presidential employees that "tended to demonstrate that the military made certain decisions with respect to the operation of the flight on the day in question." Id. As discussed in footnote 134, supra, the limited amount of information before the court in McMahon may be how to reconcile its ruling which followed with the subsequent Carmichael decision.

148. Id. (emphasis in original).

149. Id. at 1361 .

150. Id. at 1363 .

151. Id. at 1364. The court seemed to change its characterization of the relevance of Afghanistan to the crash in McMahon. In Carmichael, the Eleventh Circuit referred to the flight in McMahon as "more or less a routine airplane flight" and that the fact that the crash took place over Afghanistan during wartime "was incidental." Carmichael Appeal, 572 F.3d 1271, 1290-91 (9th Cir. 2009). In Carmichael, the court attempted to distinguish McMahon on the grounds that military activities in Afghanistan were not related to the accident, while the convoy operation to deliver fuel in Carmichael was "utterly central" to the military. Id. at 1291. While delivering fuel is undoubtedly important, the aircraft in McMahon was transporting three service members, including a Lieutenant Colonel and a Chief Warrant Officer, in Afghanistan. McMahon I, 502 F.3d at 1336. Movement of military members on the battlefield would seem to be either "utterly central" to, if not a military 
the court will simply have to determine whether the choices made were negligent."152

Other courts have not had the same success as Lessin and McMahon in identifying the proper decision making level at which to evaluate whether a suit implicates the political question doctrine. Adjudicating the political question doctrine in wartime contractor litigation is daunting - courts must apply a loosely defined doctrine to situations arising from two complex U.S. led wars in which contractors play a much greater role in proportional numbers and functional diversity than ever before. Further complicating matters, litigants each pursue their own agendas with plaintiffs couching complaints as little more than the "red car/blue car" traffic accident of law school torts, and defendants claiming that judges who would hear cases like these overstep constitutional bounds and intrude on the executive branch. Changes in how the government views and employs contractors, and its conspicuous absence from the litigation in which contractors have asserted the political question doctrine, make the challenge courts face greater still.

IV.

\section{The GOVERnMENT'S ROLE IN CREATING CONFUSION (OR AT LEAST NOT HELPING TO CLARIFY)}

\section{A. Changes in How the Government Views Contractors}

According to the Congressional Research Service, "[n]ot since the 17th century has there been such a reliance on private military actors to accomplish tasks directly affecting the success of military engagements. Private contractors are now so firmly embedded in intervention, peacekeeping, and occupation that this trend has arguably reached the point of no return."153 Others refer to contractors as a "fourth branch of government" 154 and "quasi agencies" of the

activity outright.

152. McMahon I, 502 F.3d at 1364 (9th Cir. 2007). Yet, as noted earlier, the court was unwilling to follow that approach in Carmichael.

153. CRS, supra note 1, at 2 (quoting Fred Schreier \& Marina Caparini, Privatizing Security: Law, Practice and Governance of Private Military and Security Companies, Geneva Center for the Democratic Control of Armed Forces, 1 (March 2005)). See Zamparelli, supra note 3, at 9 (stating that "[n]ever has there been such a reliance on nonmilitary members to accomplish tasks directly affecting the tactical successes of an engagement."). See generally, P.W. SINGER, CORPORATE WARRIORS: THE RISE OF THE PRIVATIZED MILITARY INDUSTRY (2003) (detailing the evolution of the military service industry and privatization of warfare).

154. Scott Shane \& Ron Nixon, U.S. Contractors Becoming a Fourth Branch of Government, INT'L HERALD TRIBUNE, Feb. 4, 2007, available at http://www.iht.com/articles/ 2007/02/04/america/web.0204contract.php. Shane and Nixon contend that the government's "reflexive answer to almost every problem" is to "hire another contractor" and that "the most successful contractors are not necessarily those doing the best work, but those who have mastered the special skill of selling to Uncle Sam." Id. 
federal government. ${ }^{155}$

The Joint Chiefs of Staff attribute DoD's increased reliance on contractors to a host of factors, including:

reductions in the size of military forces (especially in the combat support and combat service support areas), increases in operations tempo and missions undertaken by the military, increased complexity and sophistication of weapon systems, and a continued push to gain efficiencies and reduce costs through the outsourcing or privatizing of commercially adaptable functions. ${ }^{156}$

This increased reliance has rendered contractor support to the DoD a "core logistic capability" which provides a military commander the "ability to synchronize and integrate both the delivery of service, agency, and other government organization contract support."157 Despite this recognition of contractor importance, according to a descriptively titled GAO report, DoD plans do not adequately address contractors. ${ }^{158}$ The GAO found that while DoD relies on contractors "to supply a wide variety of services," DoD and the military services "could not quantify the totality of support that contractors provide to deployed forces around the world." 159

The government's relationship with contractors appears erratic. It values and increasingly relies on contractors, ${ }^{160}$ including them and their functions in military doctrine manuals, yet it does not adequately plan for contractors and does not track when contractors are wounded or killed. ${ }^{161}$ In some instances, the government does not even know how many contractors it employs. ${ }^{162}$ Further complicating questions of tort liability and the applicability of the political question doctrine, the government has changed how it views contracts. ${ }^{163}$ Moreover, it remains conspicuously absent from litigation over tort

155. Singer, supra note 153 . According to Singer, "[w]e've created huge behemoths that are doing 90 or 95 percent of their business with the government....[t]hey're not really companies, they're quasi agencies." Id. at 6 . Yet Singer refers to the use of Brown and Root to provide logistics for U.S. military forces deployed in and around Kosovo instead of calling up 9,000 reservists as "one of the quiet triumphs of the war in Kosovo." Id.

156. JOINT PUB. 4-0, supra note 4.

157. Id.

158. Gen. Acct. Office, Pub. No. GaO-03-695, Military Operations: Contractors Provide Vital Services to DePloyed Forces but ARE Not AdEQuately AdDRESSEd in DOD PLANS 1 (2003).

159. Id.

160. But see Cam Simpson \& Christopher Conkey, Obama Aims to Reduce Reliance on Contractors, WALL ST. J., Feb. 22, 2009, available at http://online.wsj.com/ article/SB123578119096998007.html (reporting that through a budget blueprint President Obama seeks to roll back "Washington's dependence on private sector contractors" but also noting that "the lack of specifics [in the blueprint] suggests the difficulty of the task").

161. GAO, supra note 1 , at 27-28,33, and 38. See Schooner, supra note 5 .

162. GAO contractor tracking, supra note 5 .

163. As discussed earlier, the government employs contractors to perform the inherently governmental function of interrogation and several lawsuits against contract interrogators are 
claims arising from contract performance, which only obfuscates its relationship with contractors and the resulting judicial inquiry into their potential liability.

\section{B. Changes to How the Government Views Contracts}

Largely absent from cases thus far is any discussion of the U.S. government's shift to performance-based acquisition, which changed how the executive branch views and structures the contracts underlying the litigation. ${ }^{164}$ Performance-based acquisition is "a technique for structuring all aspects of an acquisition around the purpose and outcome desired as opposed to the process by which the work is to be performed." 165 The concept is not new, having been around since the 1990s. ${ }^{166}$ The 2001 NDAA established a preference for performance-based contracts. ${ }^{167}$ The preference is now a requirement under the Federal Acquisition Regulations ${ }^{168}$ and a separate approval process is required if an acquisition for services is not performance-based. ${ }^{169}$

Performance-based acquisition would seem to aid at least the framework by which some of the plaintiffs attempt to argue their case, while undermining the contractor defendants' arguments. In an acquisition for logistics services, which form the basis for the convoy related litigation previously discussed, the government's focus is now required to be on purpose and outcome, and not, as contractors argue, on dictating or controlling specific details of logistic convoy operations.

ongoing. See supra Part III.A.

164. The U.S. Court of Appeals for the D.C. Circuit did discuss performance based contracting in Saleh, but not in the context of the political question doctrine. See Saleh v. Titan Corp., 580 F.3d 1 (D.C. Cir. 2009).

165. The term performance based acquisition replaced the term performance based contracting. See General Services Administration, Performance-Based Acquisition, http:/www.gsa.gov /Portal/gsa/ep/contentView.do?contentType=GSA_OVERVIEW\&contentId=15922 [hereinafter Performance Based Acquisition].

166. Id.

167. The Floyd D. Spence National Defense authorization Act for Fiscal Year 2001, Pub. L. No. 106-398, §821 (2001).

168. See 48 C.F.R. $\S 37.000$ (2009) (requiring "the use of performance-based acquisitions for services to the maximum extent practicable and prescribing policies and procedures for use of performance-based acquisition methods")

169. See 48 C.F.R. $\$ 7.105$ (b)(4) (requiring that a written acquisition plan "[p]rovide rationale if a performance based acquisition will not be used or if a performance-based acquisition for services is contemplated on other than a firm fixed- price basis"); U.S. DEP'T OF DEFENSE, DEFENSE FEDERAL ACQUISITION REG. SUPP. $§ 237.170-2$ (2009) (describing the required approval process to acquire services through a non performance-based contract); U.S. DEP'T OF ARMY, ARMY FEDERAL ACQUISITION REG. SUPP. pt. 5137.590-1 (2007) (stating that the Army acquisition team will "focus on the importance of developing and maintaining sound acquisition strategies to ensure services are properly planned, based upon clear, performance-based requirements and acquired by sound business practices"). 


\section{Conspicuous Silence}

Despite the important role contractors play in today's military, in the host of contractor related litigation where the government is not a party and the political question doctrine has been raised, there is not a single reported case of the government intervening or submitting an amicus curiae brief to the court. The closest the government seems to have come was in Lane, discussed above. ${ }^{170}$ During the pendency of the appeal in Lane, the Department of Justice (DoJ) filed a motion requesting an extension of time to file an amicus curiae brief. ${ }^{171}$ Having received the requested extension, the following month the DoJ filed a letter with the Fifth Circuit "advising that an amicus brief will not be filed."172

The fact that the United States is not a party to the litigation does not, in itself, preclude the application of the political question doctrine by the court. ${ }^{173}$ But what, if anything, may a court permissibly infer from the government's lack of involvement in a case in which a defense contractor is asserting the political question doctrine as a defense? Answering that question requires consideration of the political question doctrine beyond battlefield contractor litigation. Courts have also given mixed signals in this broader category of cases. For example, the Ninth Circuit held that silence by the government is a neutral factor ${ }^{174}$ while the Third and Eleventh Circuits have held that courts may make inferences based on the government's silence in cases involving the political question doctrine. ${ }^{175}$

The Ninth Circuit, in Alperin v. Vatican Bank, considered a suit against the Vatican Bank stemming from World War II claims issue. ${ }^{176}$ The court noted

170. Lane v. Halliburton, No. 06-1971, 2006 WL 2796249 (S.D. Tex. Sept. 26, 2006).

171. See docket entry dated May 24, 2007, Lane v. Halliburton, 529 F.3d 548 (5th Cir. 2008) (requesting extension to file an amicus brief). The published opinion lists the United States as amicus curiae.

172. See id. (approving extension); docket entry dated June 12, 2007, Lane v. Halliburton, 529 F.3d 548 (5th Cir. 2008) (reflecting notice by the government that it would not be submitting a brief).

173. See U.S. v. Munoz-Flores, 495 U.S. 385, 394 (1990) (stating that the identity of the parties is immaterial to the presence of the political question doctrine in a particular case).

174. Alperin v. Vatican Bank, 410 F.3d 532, 556 (9th Cir. 2005). See Assicurazioni Generali S.p.A. Holocaust Insurance Litigation, 340 F. Supp 2d 494, 506 (S.D.N.Y. 2004) (stating that "the Government's decision to intervene, or not, in a particular case relating to foreign affairs, and what form its intervention should take were it to do so, is informed by a variety of intricate diplomatic and political consideration that make this sort of inferential reasoning by a courts a perilous enterprise").

175. See Gross v. German Foundation Industrial Initiative, 456 F.3d 363 (3rd Cir. 2006); McMahon v. Presidential Airways, 502 F.3d 1331 (9th Cir. 2007). The U.S. Court of Appeals for the D.C. Circuit discussed that the government had not chosen to intervene in Saleh or file an amicus brief, but not as related to the political question doctrine. Saleh v. Titan Corp., 580 F.3d 1, 10 (D.C. Cir. 2009).

176. Alperin, 410 F.3d at 556. 
that "[a]lthough the political question doctrine often lurks in the shadow of cases," the doctrine is "infrequently addressed head on."177 Nonetheless, the court found that the political question barred part of the suit. ${ }^{178}$ Much like its practice in the contractor litigation, the United States did not intervene or inform the court of the government's view as to whether the political question doctrine should apply in Alperin. The court addressed this lack of involvement in stating that "[i]t is unclear, however, how courts should construe executive silence. We are not mind readers. And, thus, we cannot discern whether the State Department's decision not to intervene is an implicit endorsement, an objection, or simple indifference. At best this silence is a neutral factor."179

In the Third Circuit, Gross v. German Foundation Industrial Initiative involved a foundation seeking additional funds to pay victims of Nazi era wrongs. ${ }^{180}$ The United States was not a party to the litigation, and its correspondence to the court stated that it did not have a position as to the justiciability of the case. ${ }^{181}$ The Third Circuit also noted that the United States could have intervened in the case or petitioned the court to participate as amicus curiae, but did not. ${ }^{182}$ In the end, the court determined that the political question doctrine did not apply, at least in part, "[b]ecause the United States Executive has declined to take a take a formal position on the justiciability of this case. . "183

The McMahon case is even more instructive on this point, as it involved allegations of wartime contractor liability and the court was even more direct in its assessment of the government's silence. ${ }^{184}$ In upholding the district court's denial of Presidential Airways' motion to dismiss on political question grounds, the Eleventh Circuit stated that "[w]e note that to this point, the United States has not intervened in the instant case, despite an invitation to do so . . The apparent lack of interest from the United States to this point fortifies our conclusion that the case does not yet present a political question." 185

The absence of U.S. involvement in cases involving the political question doctrine is even more striking when compared with U.S. involvement with

\footnotetext{
177. Id. at 538 .

178. Id. at 537.

179. Id. at 556 .

180. Gross, 456 F.3d at 363.

181. Id. at 384-95.

182. Id. at 385 .

183. Id. at 363 . The Third Circuit reversed the trial court decision that the political question doctrine applied.

184. McMahon v. Presidential Airways, 502 F.3d 1331, 1365 (9th Cir. 2007).

185. Id. This suggests that the Eleventh Circuit's view on drawing inferences requires not just government silence, but silence following an express judicial invitation to comment.
} 
another doctrine which also involves justiciability, the act of state doctrine. ${ }^{186}$ In these cases, the government developed "the Bernstein Letter" whereby the DoS informs the court if the executive branch believes that the act of state doctrine applies to pending litigation. ${ }^{187}$

So why hasn't the government made its views known in significant battlefield-related tort litigation wherein contractors have asserted the political question doctrine in an attempt to preclude a court from hearing the case? One likely possibility is that by expressing its view on the applicability of the political question doctrine in a given case the executive branch would favor one side of the litigation over the other. This is an outcome which, particularly when U.S. service members are suing contractors, the government may wish to avoid. ${ }^{188}$ For other plaintiff categories, the government likely does not want to involve itself in litigation between private contractors. Likewise, it would be problematic for the executive branch to submit a position to the court on the applicability of the doctrine to suits by persons it was responsible for detaining at Abu Ghraib. Moreover, if the executive branch's position were that the doctrine does not apply, then it would increase the chances of successful litigation success against companies with which it has billions of dollars of contracts and upon which its continued operation depends. On the other hand, if the executive branch's position is that the doctrine does apply, the case against the contractor might be dismissed, but, at least as regards the Abu Ghraib plaintiffs, it might also result in the executive branch having to explain to at least two treaty bodies whether the required remedy exists for former detainees who allege torture. ${ }^{189}$

In not submitting a position to the courts on contractor litigation involving the political question doctrine, the government may avoid initial offense to one party but almost ensures offense to both in the end. Also, somewhat counterintuitively, by remaining silent on the applicability of the political question doctrine, the government likely creates more work for itself, not less. ${ }^{190}$ Without the government's input, courts inefficiently grapple with the

186. ANDREAS F. LOWENFELD, INTERNATIONAL LITIGATION AND ARBITRATION THIRD EDITION 529 (2006) (referring to Bernstein v. N.V. Nederlandsche-Amerikaansche StoomvaartMaatshcappij, 210 F.2d 375 (2d Cir. 1954)).

187. Id.

188. Id.

189. See Convention Against Torture and Other Cruel, Inhuman, and Degrading Treatment or Punishment, art. 14(1), Dec. 10, 1984, 1465 U.N.T.S. 85, 113; S. Treaty Doc. No. 100-20 (1988); 23 I.L.M. 1027 (1984) (requiring "that the victim of an act of torture obtains redress and has an enforceable right to fair and adequate compensation"); International Covenant on Civil and Political Rights, Dec. 16, 1966, 999 U.N.T.S. 171; S. Exec. Doc. E, 95-2 (1978); S. Treaty Doc. 95-20, 6 I.L.M. 368 (1967) (requiring "that any person whose rights or freedoms as herein recognized are violated shall have an effective remedy, notwithstanding that the violation has been committed by persons acting in an official capacity").

190. There is also the possibility that by not submitting a statement to the court in cases in 
competing characterizations of how the executive branch is or is not implicated by the questions the case presents. Furthermore, regardless of which way the court rules on the political question doctrine, either or both sides will likely attempt to engage the government by seeking declarations and trying to subpoena testimony and documents from it. In this way, the government will likely become involved, even when it does not submit its views to the court, jeopardizing both the efficiency of the process and control over its involvement. It seems reasonable to conclude that the lack of government involvement has played a role in the inconsistent application of the political question doctrine to wartime contractor litigation and that this, in turn, increases the chances that the Supreme Court will hear an appeal and provide guidance on the doctrine-an outcome the government may also want to avoid. If avoiding Supreme Court intervention is the government's goal, then not appearing in any of the cases and remaining silent on executive's view would not seem to further that goal. Indeed, the chance that the political question doctrine may return to the Supreme Court through a government contractor battlefield related tort case seems increasingly likely. 191

$\mathrm{V}$.

\section{InCONSISTENT APPLICATION, RESUlting CONFUSION, AND the WAy AHEAD}

The situation in Iraq has improved in the past year. Iraq now assumes responsibility for detainees and convoys are rarely attacked. ${ }^{192}$ This might lead

which the political question doctrine should apply, the government may end up reimbursing the contractor defendants for their litigation costs under some contract structures. In suits by service members, this would be an odd result as service members are generally precluded from suing the government in tort. There seems little functional difference between a service member suing the government directly as opposed to suing and recovering from a contractor, who in turn is reimbursed by the government. See FAR $\S 52.228-7$ (c), which provides for a contractor to be reimbursed for "liabilities" arising out of the performance of the contractor, including for death and bodily injury. But see Risk/Liability to Third Parties/Indemnification, 73 FED. REG. 62 (Mar. 31, 2008) (to be codified at 48 C.F.R. pt. 252.225-7040(b)(2) (referencing contractor concern for the availability of indemnification and stating that contractors are accountable for the negligent or willful actions of their employees, including subcontractors. In the Federal Register, the government reiterates the view that under performance based contracting, the government "does not, in fact, exercise specific control over the actions and decisions of the contractor").

191. As of this Article, the Fifth Circuit in Fisher found the doctrine did not apply to a convoy attacked by insurgents while the Eleventh Circuit in Carmichael found that the doctrine did apply in a vehicle crash. In similar fashion, the Court of Appeals for the D.C. Circuit dismissed the Saleh interrogator cases (although not expressly on political question doctrine grounds) while a district court within the Fourth Circuit has ruled that the doctrine does not preclude the Al-Shimari interrogator cases.

192. However, as the situation in Iraq has improved it has deteriorated in Afghanistan. As the United States shifts its attention and the focus of its total military force to Afghanistan, it will be interesting to see if there is a corresponding spike in lawsuits filed against contractors. This raises the question of how much the intensity (or lack thereof) of combat operations weighs in the judicial 
one to question whether the cases arising from the treatment of detainees or the conduct of convoys in Iraq have any enduring significance, if the underlying incidents which generated the litigation are not likely to be repeated. However, interrogating detainees and driving logistics convoys are just two manifestations of a broader phenomena-the United States military's extensive reliance on private contractors and the occurrence of tort incidents that inevitably result, whether between contractors and local nationals, U.S. service members, or other contractors. ${ }^{193}$

As courts attempt to distinguish contractor tort cases involving the political question doctrine from each other, the resulting jurisprudence promises problems for both present and future litigants. One theory explaining this is that the current difficulty flows from Baker $v$. Carr, the lead case establishing the tests for applying the political question doctrine. ${ }^{194}$ The Baker tests have proven an unsteady foundation for political question doctrine jurisprudence. Courts have wrestled with the Supreme Court's requirement to avoid "semantic cataloguing" 195 yet "analyze representative cases and to infer from them the analytical threads that make up the political question doctrine."196 The current political question doctrine decisions in battlefield contractor litigation are the analytical threads upon which future decisions may unfortunately attempt to rely. Some might argue that, even if the Baker tests were useful when announced, the real cause of the current difficulty is the unique collision of the conflicts in Iraq and Afghanistan and the burgeoning use of contractors in roles traditionally reserved for the government; a collision which neither the political question doctrine nor the judiciary appear well-equipped to handle.

Issues of justiciability are a contradiction of sorts, as courts must consider detailed aspects of a case just to determine whether the court may permissibly

calculus. In any case, it seems clear that type of litigation treated here is not likely to disappear any time soon.

193. In demonstration of the inevitability of future litigation and perhaps the start of the next wave of contractor litigation involving the political question doctrine, see Complaint, Harris v. KBR, No. 08-0563 (W.D. Penn. Apr. 22, 2008), a suit filed by the parents of Staff Sergeant (SSG) Ryan Maseth, a U.S. Army Special Forces Soldier, or "Green Beret," electrocuted in Iraq while in the shower of a building allegedly maintained by KBR. At least 18 U.S. service members have been electrocuted in Iraq, the total number of injured and killed in Iraq and Afghanistan is likely higher. See Scott Bronstein \& Abbie Boudreau, Sources: Contractor for military committed serious violations, CNN.com, Nov. 24, 2008, http://www.cnn.com/2008/US/11/24/soldiers.electrocuted/ index.html. See also Kimberly Hefling, State Dep't contractor electrocuted, Associated Press, Sep. 8. 2009, available at http://www.google.com/hostednews/ap/article/ALeqM5htvFRJgKa3 fGet485w0NBH1e3KeQD9AJGRO00. (detailing the September 2009 electrocution of a DoS contractor in Baghdad, Iraq).

194. Professor Chemerinksy has labeled the Baker v. Carr criteria "useless" and impossible to apply to determine which cases present political questions. CHEMERINSKY, supra note 16, at 143145.

195. Baker, 369 U.S. at 217.

196. Id. at 211 . 
consider the case. ${ }^{197}$ Even so, similar cases should yield similar, not widely disparate, outcomes. The fundamental questions remain: when should the political question doctrine apply to wartime contractor tort litigation? How does one balance the fact that incidents occur as a direct result of or in the shadow of combat operations with the recognition that " $[t]$ he Constitution's allocation of war powers to the President and Congress does not exclude the courts from every dispute that can arguably be connected to "combat?"'198

It would be wise for the gövernment to acknowledge the inevitability of litigation resulting from the sheer number of contractors it currently employs and the functions they perform. More importantly, the government should recognize that by not involving itself in the litigation, it creates more work and expense for the judiciary and sacrifices the opportunity to influence the litigation and, thereby, prevent not only inconsistent case results but their unintended and unforeseen consequences over time.

For their part, courts should recognize that the terms combat and wartime are little more than labels that add little to the legal analysis in and of themselves. ${ }^{199}$ Several of the "wartime" convoy accidents do not involve any relevant wartime condition-vehicles run into each other or off the road the world over. Similarly, analysis which focuses exclusively on operational control would seem to logically lead to the application of the political question doctrine to convoy accidents not only in Iraq but also in non-war zones, including domestic operations on U.S. soil. This extrapolation not only demonstrates that the operational control test can be a red herring, but also that applying the test without linking that control to decisions and causes relevant to the incident is unproductive and often results in confusing and inconsistent outcomes. Finally, courts should also take cognizance of the analytical pitfalls associated with both the macro and micro level approach to assessing the facts of these contractor liability cases.

If the application of the political question doctrine to wartime contractor tort liability is so unwieldy, is there an alternative? One commentator has suggested revising and possibly expanding the Defense Base Act (DBA). ${ }^{200}$ The DBA provides workers' compensation protection to civilian employees working outside the United States on U.S. military bases or under a contract with the U.S.

197. That the U.S. requires only notice pleading makes justicability determinations that much harder.

198. Ibrahim I, 391 F. Supp. 2 d at 15 (citing Hamdi v. Rumsfeld, 542 U.S. 507, 526-35 (2004)).

199. Such terms leave doubt as to when, where, and for how long a state of "wartime" exists. Assigning a "wartime" label leads to these inquiries which are of little utility absent some nexus between the wartime condition and the incident.

200. 42 U.S.C. $\S \S 1651-1654$ (2006). For a discussion on the Act's revision and expansion, see Jeremy Joseph, Striking the Balance: Domestic Tort Liability for Private Security Contractors, 5 GEO. J.L. \& PUB. POL'Y 691, 718 (2007) (recommending that the Defense Base Act should be the sole remedy for private security companies' negligence towards their employees). 
government for public works or for national defense. ${ }^{201}$ However, even with this approach, significant changes would be required for the DBA to address the categories of plaintiffs and causes of action, including intentional tort claims, addressed in this Article. ${ }^{202}$ Additionally, the NDAA may limit future problems as it restricts security contractors from performing inherently governmental functions in an area of combat operations.

This author suggests an alternative methodological approach to these cases wherein the court would seek to determine: (1) whether the suit arises from actions taken by a contractor in war zone, defined as geographic locations where U.S. service members are eligible for "imminent danger pay"; (2) whether the U.S. military controlled the actions taken by the contractor either directly or through contract requirements; and (3) how the military operational control, decision making, or actions are relevant to, or a cause of, the incident at issue. The first prong of the analysis is a threshold inquiry designed to focus the inquiry on what "wartime" condition makes a fact in issue for the litigation more or less likely. The second prong moves past abstract Constitutional arguments to the specifics of whether there is governmental conduct relevant to the litigation. The final prong is designed to identify where on the causation spectrum that conduct or control lies and whether the political question doctrine should apply. Where the court determines the government's role to be an attenuated cause or no cause at all, the doctrine would not apply. However, as characterization of the government's role moves along the spectrum toward direct cause, or in the easiest application of the methodology, the proximate cause, the doctrine would apply.

The benefit of this proposed methodology is that it would provide courts a tether to a more finite analytical framework while amidst the amorphous Baker v. Carr tests. Courts applying such a framework would glean true analytical threads, relevant to the disposition of the case at bar and helpful to instilling a modicum of predictability in how the judiciary approaches whether the political question doctrine applies to a wartime related contractor tort suit. This, in turn, would lead to more consistent outcomes, which better inform prospective litigants as to the viability of their claim or defense. In the end, the likely outcome of these developments being fewer suits filed and quicker out of court resolution of those which are.

201. Department of Labor Office of Workers Compensation Programs, available at http://www.dol.gov/esa/owcp/dlhwc/lsdba.htm (last visited Jan. 22, 2010).

202. See Lane Appeal, supra note 101, at 556. (outlining KBR's arguments that both the DBA and the political question doctrine bar Plaintiff's suit). In the case of KBR's DBA argument, neither the district or Fifth Circuit courts addressed this question in their decisions. Appellant Reply Brief at 2, Lane v. Halliburton, 529 F.3d. 548 (5th Cir. 2008) (No. 06-20874) (arguing that the DBA provides contractors a defense to contract based theories of liability, but not those based in torts). 
VI.

\section{CONCLUSION}

The purpose of this Article is not to argue for or against the applicability of the political question doctrine, in general or in any particular case. Instead, it seeks to shed light on the inherent difficulties courts face in applying a confusing justiciability doctrine, the political question doctrine, to wartime contractor tort litigation and to draw attention to difficulties enhanced by the government's diverse use of contractors and lack of involvement in the litigation which follows. This Article seeks to identify and separate those judicial approaches and methods of analysis which cloud the issue from those which clarify. In so doing, the Article proposes a new framework for considering these cases which, although not exhaustively discussed, the author believes provides a starting point for drawing out the elusive analytical threads that might prove be helpful in future cases. 